\title{
Virulence Factors of Meningitis-Causing Bacteria: Enabling Brain Entry across the Blood-Brain Barrier
}

\author{
Rosanna Herold, Horst Schroten and Christian Schwerk*
}

Department of Pediatrics, Pediatric Infectious Diseases, Medical Faculty Mannheim, Heidelberg University, 68167 Mannheim, Germany; rosanna.herold@medma.uni-heidelberg.de (R.H.); horst.schroten@umm.de (H.S.)

* Correspondence: christian.schwerk@medma.uni-heidelberg.de; Tel.: +49-621-383-3466

Received: 26 September 2019; Accepted: 25 October 2019; Published: 29 October 2019

\begin{abstract}
Infections of the central nervous system (CNS) are still a major cause of morbidity and mortality worldwide. Traversal of the barriers protecting the brain by pathogens is a prerequisite for the development of meningitis. Bacteria have developed a variety of different strategies to cross these barriers and reach the CNS. To this end, they use a variety of different virulence factors that enable them to attach to and traverse these barriers. These virulence factors mediate adhesion to and invasion into host cells, intracellular survival, induction of host cell signaling and inflammatory response, and affect barrier function. While some of these mechanisms differ, others are shared by multiple pathogens. Further understanding of these processes, with special emphasis on the difference between the blood-brain barrier and the blood-cerebrospinal fluid barrier, as well as virulence factors used by the pathogens, is still needed.
\end{abstract}

Keywords: bacteria; blood-brain barrier; blood-cerebrospinal fluid barrier; meningitis; virulence factor

\section{Introduction}

Bacterial meningitis, as are bacterial encephalitis and meningoencephalitis, is an inflammatory disease of the central nervous system (CNS). It can be diagnosed by the presence of bacteria in the CNS. Despite advances in treatment, it is still a disease of global dimension, which can end fatally or leave long-term neurological sequelae in survivors [1].

The brain is well protected from invading pathogens by cellular barriers, with the two major barriers being the blood-brain barrier (BBB) and the blood-cerebrospinal fluid barrier (BCSFB) [2,3]. To reach the CNS, blood-borne bacteria must interact with and cross these barriers of the brain. During the course of infection attachment to the host cells is initiated, followed by the hijacking of several host cell pathways by the pathogens. This process can be used by the bacteria to enter host cells with subsequent intracellular survival and, for some pathogens, multiplication. Finally, after crossing into the brain, the bacteria elicit an immune response from the cells within the CNS that might contribute to the inflammatory events leading to disease, with potential disruption of barrier integrity [4].

The traversal or breach of these barriers by meningitis-causing pathogens is defined by a complex interplay between host cells and the pathogens, which use an array of virulence factors to facilitate this interaction, resulting in high morbidity and mortality [1]. These virulence factors are involved during protection in the bloodstream, such as the capsule of both gram-positive and gram-negative bacteria, mediate adhesion to and invasion into host cells, and are responsible for intracellular survival.

\section{Barriers of the Central Nervous System}

The barriers protecting the brain are essential for its function and the stability of its internal microenvironment [5]. Important morphological components found in most of these barriers are 
specialized intercellular tight junctions between the cells, which are the basis for the barrier property. Various transporters, such as ATP-binding cassette (ABC) transporters, as well as efflux pumps control the movement of molecules across these interfaces, making them another component of barrier function [6]. These mechanisms prevent substances such as toxins, pharmacologically active agents and pathogens from accessing the CNS $[4,7,8]$.

\subsection{Blood-Brain Barrier}

The BBB is formed by brain microvascular endothelial cells (BMECs), astrocytes and pericytes. It presents a structural and functional barrier and acts as an interface between the CNS and the peripheral circulation [2,9]. It has an additional protective function, restricting the free movement of substances across and inhibiting the entry of pathogens and toxins into the CNS. By regulating the passage of molecules, it is furthermore responsible for maintaining the CNS homeostasis.

The structure of the BBB is defined by BMECs covering the inner surface of the capillaries by forming a continuous sheet of cells interconnected by tight junctions (TJs) [10]. Specific TJ proteins, including occludin and, at the BBB, claudin-5, and claudin-12, but not claudin-3, are responsible for limiting the paracellular diffusion of ion and solutes across the barrier [11,12]. BMECs are characterized by less cytoplasmic vesicles, a larger number of mitochondria and a high amount of intercellular junctions, resulting in a high transendothelial resistance and low paracellular flux [13]. Transporter systems of the BBB include solute carrier-mediated transport, receptor-mediated transport, as well as active efflux and ion transport [14]. The BMECs are supported in shaping the BBB by associated cells such as astrocytes and pericytes [10]. The mechanisms of microbial CNS invasion have been elucidated by the use of in vivo and in vitro studies. To model infections of the CNS, mice and rats are most commonly used. To model the BBB in in vitro cell culture systems, primary human, rodent, and bovine brain microvascular endothelial cells have been used. Extensive studies of the human BBB have been facilitated by the availability of immortalized brain endothelial cells such as human brain microvascular endothelial cells (HBMECs) and hCMEC/D3 [1].

\subsection{Blood-Cerebrospinal Fluid Barrier}

Another major barrier protecting the brain is the BCSFB, which can be separated into a barrier to the inner CSF in the ventricles at the choroid plexus (CP) and barriers to the outer CSF located at the arachnoidea and blood vessels present in the subarachnoidal space [15]. Importantly, the choroidal BCSFB is essential in the trafficking of immune cells into the CNS $[3,16]$. The epithelial cells displaying polarity and forming tight junctions, which specifically express claudin- $-1,-2,-3$, and -11 , are the morphological correlates of the BCSFB at the CP [3,11,12]. The presence of specific transporter systems, such as $\mathrm{ABC}$ transporters, and low pinocytotic activity regulating the crossing of substances are key characteristics of the CP $[17,18]$. Furthermore, the BCSFB is crucial for the protection of the CNS from pathogens [19].

To cause diseases of the CNS bacterial pathogens need to overcome these barriers [1,17]. During this process, several different steps are influenced by bacterial virulence factors. To analyze the role of the $\mathrm{CP}$ during infectious diseases of the CNS, animal models can be utilized. Important tools for studying the BCSFB in vitro are primary models of $\mathrm{CP}$ epithelial cells, such as primary porcine $\mathrm{CP}$ epithelial cells (PCPEC). Another functional model of the BCSFB is a human CP epithelial papilloma cell line (HIBCPP cells) which displays apical/basolateral polarity and a good barrier function [17].

\section{Stages during the Pathogenesis of BACTERIAL Meningitis}

Bacterial meningitis can be caused by a variety of different gram-positive and gram-negative pathogens. There are mechanisms and steps of disease progression that are similar among them as shown in Figure 1. Colonization of the mucosal surfaces is often the first step of disease progression, followed by different strategies of dissemination into the bloodstream [4]. Once the pathogens have entered the bloodstream and successfully counteracted innate and adaptive immune defenses, they 
have to translocate across the barriers of the brain to invade the CNS and cause severe inflammation. Attachment to the brain endothelium or the epithelial cells of the choroid plexus and subsequent invasion mark the initial step of translocation into the CNS [4].

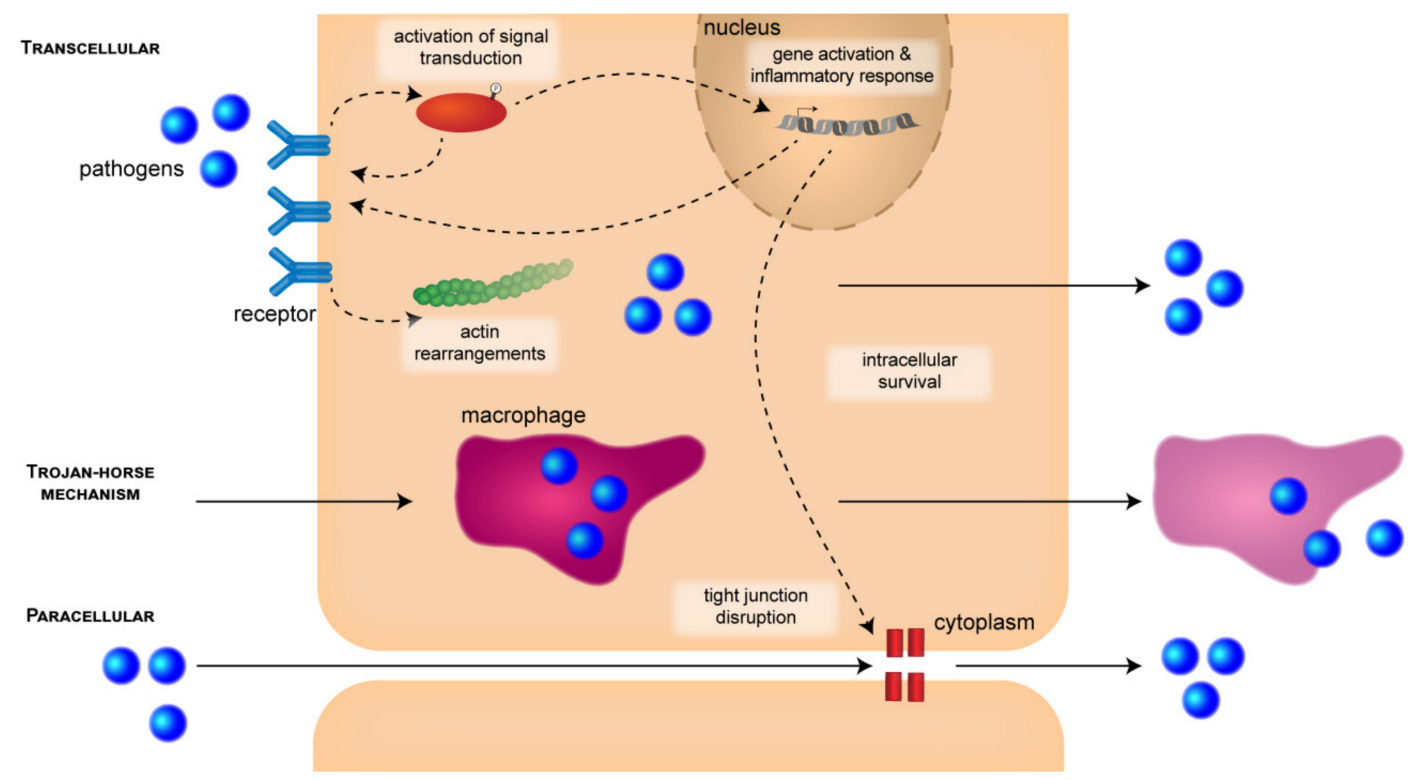

Figure 1. CNS entry pathways and stages during the pathogenesis of bacterial meningitis. Bacterial pathogens can cross the BBB or BCSFB paracellularly between neighboring cells, in a "Trojan horse" fashion inside infected host macrophages, or transcellularly by invading epithelial or endothelial cells. Cellular entry can be launched by the zipper mechanism involving binding to host cell receptors or by the trigger mechanism (see main text for details). During this process, activation of signal transduction pathways can cause initiation of actin rearrangements. Activation of signal transduction can also be triggered during the transcellular pathway or the "Trojan horse" mechanism, but is not indicated in the figure for reasons of clarity. Once in the cytoplasm, the pathogens need to survive inside the cells for further disease progress. Activation of host genes causes an inflammatory response that can lead to disruption of tight junctions.

\subsection{Attachment and Invasion}

To facilitate adhesion and invasion of the barriers protecting the brain, a threshold level of bacteremia has been shown to be required [20-22], which is correlated with the severity of infection and likeliness of developing meningitis [23]. However, direct invasion from neighboring infected tissues can occur as well.

Bacterial adhesion to host cell surfaces is a complex process. It involves multiple adhesion molecules of the pathogen interacting with a variety of target receptors. These interactions, which can involve several adhesins of one microbe, can occur in a sequential manner. Hereby, the initial interactions can trigger the expression of further host receptors, which are then targeted by other bacterial adhesins [24].

Many pathogens have been shown to bind to extracellular matrix proteins to facilitate initial attachment to the host cells. Furthermore, binding of bacterial adhesins to specific host cell receptors can in turn induce different signal transduction pathways, resulting in tight attachment or internalization of the bacteria into the host cells [4]. The use of pili or fibrils for invasion of HBMECs was observed for a multitude of meningitis-causing pathogens [8], making them highly important virulence factors for invasion of the CNS.

Endocytosis of pathogens into non-phagocytotic cells is initiated by one of two mechanisms: the "zipper" and the "trigger mechanism". Some pathogens express surface proteins capable of interacting with transmembrane receptors on the hosts cells which are connected to the cytoskeleton. 
The "zipper mechanism", in particular, is defined by an interaction of a bacterial ligand and a host-specific membrane receptor initiating signaling events that lead to internalization of the pathogen through endocytosis [25]. The "trigger mechanism" is a micropinocytosis-related process that involves formation of actin-rich membrane ruffles. These are formed by localized changes in actin dynamics and membrane remodeling triggered by delivery of active effectors, which can be injected by the needle-like structure of a type three secretion system (T3SS), into the cytosol of host cells initiating signaling cascades [26,27].

\subsubsection{CNS Entry Routes}

Meningitis-causing pathogens most commonly cross host barriers in a transcellular or paracellular manner [2]. These processes are associated with protein interactions between pathogens and the host's cells. Transcellular traversal is characterized by pathogens crossing the barrier cells without evidence of TJ disruption or traversal between cells [2]. This is accomplished by intracellular invasion of the barrier cells and exploitation of signaling pathways. Paracellular traversal, on the other hand, involves penetration of pathogens between the host's cells and can occur with and without permanent disruption of TJs [2,4]. Furthermore, the release of bacterial toxins can lead to disruption of barrier function and promote paracellular traversal. Another means of entry is the "Trojan-horse" mechanism, which describes penetration of the barrier by transmigration within infected phagocytes [2]. It has been suggested that the infected phagocytes adhere to the luminal side of brain capillaries. This can occur with and without the activation of BMECs and is followed by either transcellular or paracellular traversal of the BBB [28].

\subsubsection{Signal-Transduction Mechanisms and Cytoskeletal Rearrangements}

Meningitis-causing bacterial pathogens have been shown to utilize host cell signaling molecules to facilitate infection. The mechanisms deployed can vary between the different pathogens, as well as the host tissues.

To both enter and leave the host cells, several pathogens have developed mechanisms to use the actin polymerization machinery of the host $[29,30]$. Pathogens not only use this process to spread throughout the cells, but have also developed mechanisms to subvert these regulatory mechanisms [31]. Furthermore, meningitis-causing pathogens use different signal-transduction mechanisms that result in rearrangements of the actin cytoskeleton [2]. This allows the pathogens to initiate attachment and entry of host cells, movement within and among cells as well as vacuole formation. This complex process of actin cytoskeletal remodeling can involve many factors, such as Rho-family GTPases and a variety of actin-binding proteins $[30,32]$.

The innate immune system of the host can be triggered by various molecules which are characteristic for the bacteria. These pathogen-associated molecular patterns (PAMPs) are then recognized by eukaryotic pattern recognition receptors (PRRs), which in turn induce signaling cascades such as the nuclear factor $\mathrm{kB}$ (NF- $\mathrm{kB}$ ) and mitogen-activated protein kinase (MAPK) pathways [33,34]. Activation of these signaling cascades triggers pro-inflammatory responses like the up-regulation of cytokines [35].

\subsection{Intracellular Survival}

\subsubsection{Multiplication and Intracellular Survival}

Extracellular multiplication is the most common process for propagation by pathogenic bacteria. Furthermore, replication and persistence inside host cells has been demonstrated for a variety of meningitis-causing pathogens as well [36]. Entry into the host's cells and replication within these protects the pathogens from clearance by the complement system and circulating antibodies. However, these pathogens have to overcome several cellular defense mechanisms such as the upregulation and secretion of neutrophil-specific factors in HBMECs. This response by the BBB is assumed to serve to 
recognize pathogens resulting in their clearance. However, overactivation of the cellular response through continued exposure to the pathogens could result in increased inflammation and compromised barrier integrity [8].

\subsubsection{Disruption of Barrier Integrity and Inflammatory Response}

Characteristically, bacterial meningitis is accompanied by a severe inflammatory response leading to neuronal damage. Activation of the transcription factor NF- $\mathrm{kB}$ upon invasion of the brain barrier tissues results in high levels of inflammatory cytokines in the blood and CSF [37]. This proinflammatory response can be triggered by bacterial cell wall components. Examples would include the lipopolysaccharide (LPS) for gram-negative bacteria, and lipoteichoic acid (LTA) for gram-positive bacteria. Furthermore, increased permeability of the barriers can be triggered by both bacterial toxins, as well as the initiation of host inflammatory pathways in response to the infection [38]. Tissue damage during bacterial meningitis arises from the initiated inflammatory cascade involving cytokines and chemokines, as well as proteolytic enzymes and oxidants [4]. Consequences of the release of these inflammatory substances, caused by multiplication of pathogens in the CNS, are damage of neurons and edema [39]. The hosts' immune response is therefore unable to embank infection of the CNS, and may even contribute to adverse events during bacterial meningitis [4].

The release of proinflammatory molecules not only increases permeability of the BBB but also attracts leukocytes to the CNS [40]. Cell death can be caused by cytokines, reactive oxygen species, reactive nitrogen species and matrix metalloproteinases [41-45].

\section{Roles of Bacterial Virulence Factors During Invasion Through the Barriers of the CNS}

To be able to enter the CNS, bacterial pathogens use several virulence factors, which are involved in the different steps of pathogenesis. Of major importance is the capsule of both gram-positive and gram-negative bacteria. The capsular polysaccharide has a protective function in bloodstream survival [46]. However, it was observed to attenuate invasion of the BBB and BCSFB [47-49]. This could result from electrostatic repulsion or from the masking of bacterial surface structures [8]. The necessity of the capsule for the pathogens survival in the blood but simultaneous hindrance of invasion of the host's tissues indicates a need for the regulation of capsule expression [50].

Besides the capsule, a multitude of further virulence factors are used by gram-positive and gram-negative bacteria [51]. These include, among others, adhesins and internalins, pore-forming toxins, and factors involved in intracellular movement as well as cell-to cell spread and are summarized in Figure 2. 


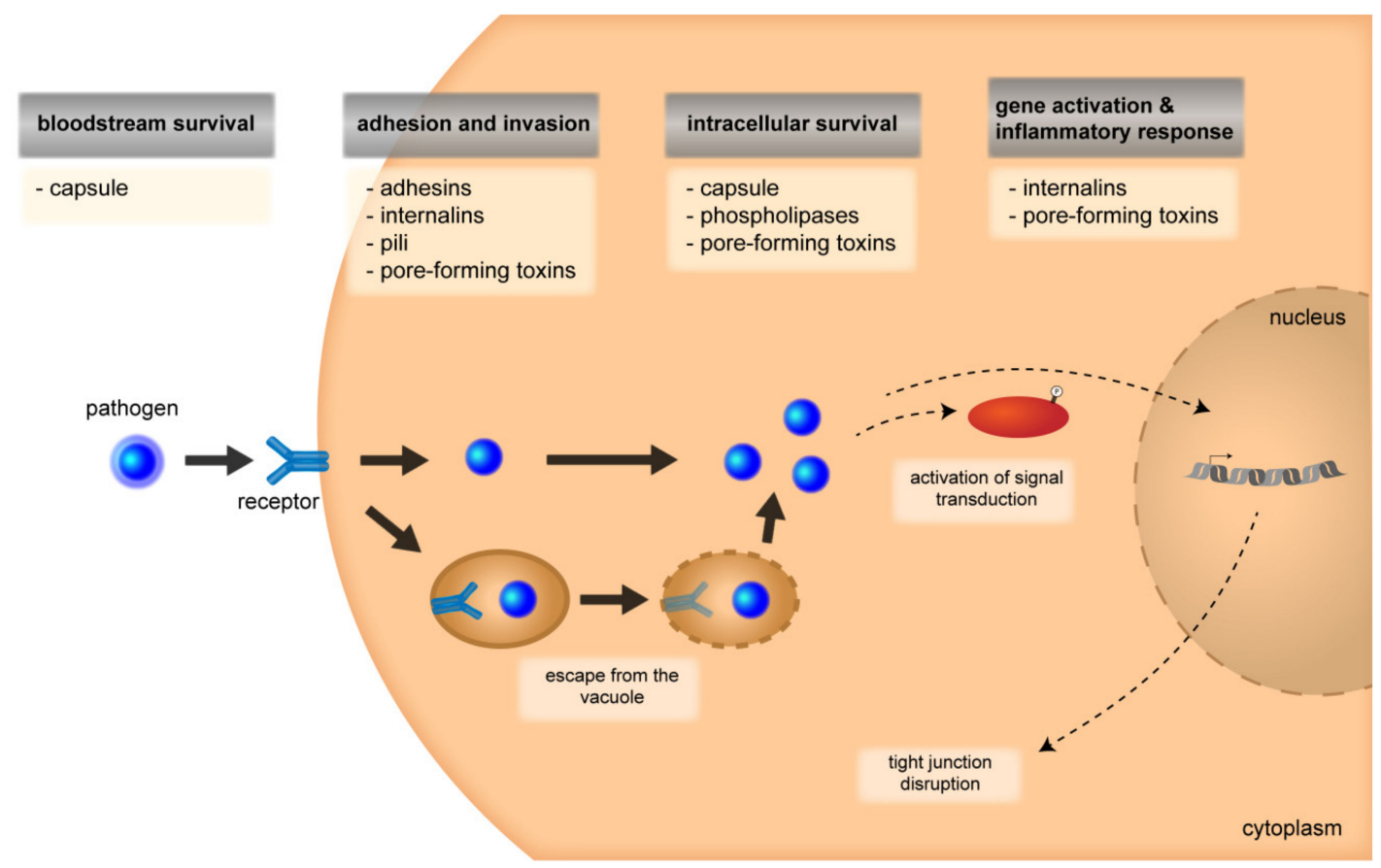

Figure 2. Multiple virulence factors are involved in the different steps of pathogenesis during bacterial meningitis. Expression of a capsule can support bloodstream survival of both gram-positive and gram-negative bacteria. It has been described that down-regulation of capsule expression occurs during adhesion to and invasion into host cells, which is mediated by adhesins, internalins, pili, and pore-forming toxins. Pore-forming toxins can also be involved during escape from vacuoles inside of host cells, as well as intracellular survival. These steps are further supported by pore-forming toxins and the capsule. Several virulence factors, including internalins and pore-forming toxins, activate host cell signal transduction and mediate gene activation causing an inflammatory response.

In this review, we will focus particularly on virulence factors, for which evidence for an involvement during brain entry across the blood-brain barriers has been proposed. A summary of these virulence factors for gram-positive and gram-negative bacteria is given in Table 1 at the end of this section.

\subsection{Gram-Positive Bacteria}

\subsubsection{Listeria monocytogenes}

Listeria monocytogenes (L. monocytogenes) is a facultative intracellular gram-positive bacterium. It can traverse several physiological barriers and finally enter the brain via the BBB or BCSFB, especially in immunocompromised individuals [52]. It is ingested through highly contaminated food by the host. Once ingested, L. monocytogenes traverses the intestinal epithelial barrier into the lamina propria followed by dissemination of the pathogen via the lymph and blood [53]. L. monocytogenes has multiple target organs, including the liver and spleen, and can enter the CNS across the barriers of the brain [53]. In addition to direct traversal of the BBB and BCSFB via the transcellular route, transportation across the BBB within leukocytes and retrograde migration within axons of cranial nerves have been described $[54,55]$.

L. monocytogenes can enter non-phagocytotic cells by hijacking the host's receptor-mediated endocytosis machinery using the zipper mechanism. The two major invasion proteins of $L$. monocytogenes are internalin (InlA) and InlB, which bind to eukaryotic cell membrane members E-cadherin and tyrosine kinase receptor protein Met, respectively. These interactions induce receptor-mediated endocytosis of the pathogen. L. monocytogenes has been demonstrated to use one or both internalins to mediate invasion of the BBB and BCSFB $[25,56,57]$. A recent study has further demonstrated the 
importance of the bacterial surface protein InlF, showing that interaction with surface vimentin was required for an optimal colonialization of the brain [58].

The MAPK signaling cascade is activated during the invasion of $L$. monocytogenes $[35,59,60]$. In a model system of the BCSFB consisting of choroid plexus epithelial cells, the requirement of MAPK activation for listerial entry was demonstrated. Both extracellular signal-regulated kinases (ERK) 1 and 2 and p38 inhibition resulted in decreased bacterial invasion into this model system suggesting their involvement in the pathogens traversal of the BCSFB [34].

It was previously described that ubiquitination of E-cadherin and Met leads to the recruitment of the clathrin-mediated endocytosis machinery. This in turn results in the polymerization of the actin cytoskeleton. During this process, dynamin recruits several factors that result in two waves of actin rearrangements and subsequently result in the entry of the pathogen inside of vacuoles [61-63]. Accordingly, an in vitro study using a model of the BCSFB based on HIBCPP cells, revealed that L. monocytogenes invasion is inhibited if dynamin-mediated endocytosis is blocked [34].

Another essential virulence factor of $L$. monocytogenes is the pore-forming cytolysin Listeriolysin $\mathrm{O}$ (LLO). Activation of the NF- $\mathrm{KB}$ signaling pathway by LLO was reported in the human embryonic kidney HEK-293 cell line [64], as well as MAPK signaling [65,66]. It is secreted by L. monocytogenes and promotes the pathogens intracellular survival. After entering the host cell, lysis of the vacuole is initiated through LLO and the bacterial phospholipases PlcA and PlcB, and followed by intracellular spread in the cytoplasm [61].

Once L. monocytogenes has reached the cytoplasm of the host's cells, it has been demonstrated to move around and enter neighboring cells using actin comet tails and membrane protrusions to facilitate its spread $[61,67]$. This F-actin-based intracellular motility is dependent on the expression of another essential listerial virulence factor, ActA [68].

Activation of the NF- $\mathrm{KB}$ signaling pathway is, as previously described, achieved through LLO. Another mechanism involving NF- $\mathrm{KB}$ is its activation by InlC, which is secreted intracellularly. It can directly interact with the subunit of the IкB kinase complex, IKK $\alpha$. By phosphorylating IKB, this complex is critical for the activation of NF- $\mathrm{kB}$, a major regulator of innate immune response. InlC was shown to impair phosphorylation of I $\mathrm{KB}$, thereby scaling down the hosts immune response [69], and is also involved in cell-to-cell spread [70].

\subsubsection{Streptococcus suis}

Streptococcus suis (S. suis) is a zoonotic gram-positive bacterium and one of the most important porcine bacterial pathogens. Serotype 2 of $S$. suis has been described to be a major cause of meningitis, especially in South and East Asia [71]. To reach the CNS, S. suis has to colonize the host and traverse epithelial barriers in order to reach the bloodstream, where it needs to survive. S. suis has been demonstrated to cross the BBB and the BCFSB in human in vitro models as well as in porcine models [48,71-73].

The presence of a capsule is essential for survival in the bloodstream. However, it was demonstrated to attenuate invasion for $S$. suis in epithelial cells $[48,72,74]$. A link between capsule expression and carbohydrate metabolism has been described, indicating adaptation of S. suis to different environments. High concentrations of nutrients, as found in the bloodstream, coincided with high expression of the capsule, whereas in the CNS, which is low in nutrients, expression was reduced [50,75]. Attachment of S. suis to BMECs has been demonstrated in human and porcine in vitro models of the BBB [76,77]. Invasion has been reported in porcine models but at very low rates [73,78]. During the adhesion process, in these in vitro model systems, the capsule had no effect on adherence [76]. In contrast, in porcine and human models of the BCSFB, both attachment and significant invasion of S. suis strains were demonstrated. The use of unencapsulated mutants further increased invasion rates, indicating a role of the capsule and regulation of its expression [48,72]. Other important virulence factors for invasion of the barriers of the brain are cell wall components such as lipoteichoic acid, LPXTG-anchored proteins as well as lipoproteins [79]. 
Also, enolase has been identified as a virulence factor of S. suis. Previously thought to act only as a glycolytic enzyme, this protein, with a highly conserved sequence, has been implicated in the invasion process of various pathogens. For S. suis, enolase has been shown to increase BBB permeability as well as promoting the release of interleukin IL-8 [80]. Transmigration might further be promoted by the thiol-activated cytolysin suilysin, which induces pore formation in membranes. Furthermore, the use of bacterial mutants lacking suilysin has shown that it is not essential for invasion of the host [81]. It has, however, been demonstrated to promote association with epithelial cells, making it another major virulence factor of the pathogen [82].

The upregulation of different cytokines and chemokines in response to $S$. suis infection in BMECs has been reported. Exemplary is the induction of IL-6 and IL-8, stimulated by S. suis [83]. An inflammatory response was also described in a porcine model of the BCSFB. Here, induction of tumor necrosis factor (TNF) $\alpha$ and matrix metalloproteinase (MMP)-3 gene expression were described. This was paralleled by rearrangements of the tight junction proteins ZO-1, occludin and claudin- 1 , and loss of actin at the apical cell pole as well as the induction of stress fiber formation at the basolateral side of the barrier [84]. The expression of TNF $\alpha$ after stimulation by S. suis in porcine choroid plexus epithelial cells further promoted adhesion and transmigration of polymorphonuclear neutrophils (PMN) through the barrier, which is a critical step during bacterial meningitis. Interestingly, some PMNs contained internalized S. suis, indicating the possibility of the pathogen exploiting the Trojan-horse mechanism [85].

\subsubsection{Streptococcus pneumoniae}

Streptococcus pneumoniae (S. pneumoniae) is a gram-positive pathogen which is the major cause of bacterial meningitis in the developing world [86]. Close to 30\% of individuals carry S. pneumoniae asymptomatically. Nasopharyngeal colonization is followed by systemic invasion and access to the bloodstream. Invasion of the CNS via the barriers of the brain is the major cause for meningitis [87]. Furthermore, olfactory neuron invasion was observed to be an entry route for S. pneumoniae [88]. To facilitate invasion of the CNS, S. pneumoniae utilizes several virulence factors such as the pneumococcal capsule and surface proteins as well as secreted proteins.

Bacterial interactions with the host and the subsequent development of bacterial meningitis are promoted by a high level of bacteremia [4]. Accordingly, attachment of S. pneumoniae to the choroid plexus in an in vivo mouse model was observed only during late stages of infection with high levels of bacteremia [87]. Further studies of the interaction with the BCSFB would be needed to determine if S. pneumoniae can use it as entry gate to the CNS.

The capacity of $S$. pneumoniae to invade host tissues is majorly determined by its capsule. Similar to other pathogens capable of causing bacterial meningitis, survival in the bloodstream is dependent on maximum capsule expression [89,90], whereas attachment to host tissues is hindered by its presence [91]. As the binding of various pneumococcal surface proteins is hindered by the capsule, altered expression of the capsule through quorum sensing and phase variation has been described $[92,93]$.

Pneumococci have been demonstrated to use multiple virulence factors to initiate attachment to HBMECs in several in vitro studies. The platelet endothelial cell adhesion molecule (PECAM-1) has been implicated as receptor for neuraminidase A (Nad A) in pneumococcal attachment [94,95]. Importantly, NadA has been described as an important virulence factor, anchored in the cell wall of $S$. pneumoniae that can cleave sialic acid of the host substrates. It has been implicated in triggering the transforming growth factor- $\beta$ (TGF- $\beta$ ) signaling cascade during the interaction with the BBB, resulting in decreased barrier integrity and an increase in invasion [96]. Another important receptor involved in pneumococcal BBB invasion is the polymeric immunoglobulin receptor (pIgR) as the major adhesin of the pneumococcal pilus-1, RrgA, was observed to bind to it as well as PECAM-1. Human platelet-activating factor receptor (PAFR) was demonstrated to be further involved in attachment, together with the before mentioned PECAM-1 and pIgR [97]. Additionally, a second type of pneumococcal pili has been described to mediate adhesion to host cells [98]. Furthermore, choline binding protein PspC was shown to bind only 
to pIgR [97], and interaction with the laminin receptor by S. pneumoniae is initiated by choline-binding protein A (CbpA) [99]. A proteome-based approach in a mouse meningitis model, addressing adaptive capabilities of the pathogens to a defined host compartment, has highlighted a crucial role for two highly expressed pneumococcal proteins; ComDE, a regulatory two-component system, and AliB, a substrate-binding protein of an oligopeptide transporter, in pneumococcal meningitis [100].

A major virulence factor of S. pneumoniae is pneumolysin, a pore-forming toxin which acts in a cholesterol-dependent manner. Pneumolysin has recently been demonstrated to induce the expression of CERB-binding protein (CBP), a coactivator of transcription. This results in the release of TNF- $\alpha$ and IL-6, which in turn lead to increased permeability of the BBB through increased apoptosis of the cells both in vivo and in vitro [101]. It has furthermore been implicated in paracellular traversal of the BBB by S. pneumoniae as a result of reduced barrier integrity [102].

In addition to the disruption of the BBB by pneumolysin, generation of $\mathrm{H}_{2} \mathrm{O}_{2}$ through $\alpha$-glycerophosphate oxidase (GlpO) was observed to have a cytotoxic effect on HBMECs [103]. A study using rat brain tissues investigated the effect of $S$. pneumoniae infection on nucleotide-binding oligomerization domain 2 (NOD2) and inflammatory factors, suggesting that NOD2 may hold a role in the activation of inflammatory pathways and subsequent BBB damage [104].

A study by Coutinho et al. analyzed the CSF of patients with pneumococcal meningitis, detecting high levels of pro-inflammatory cytokines such as TNF- $\alpha$, IL-1 $\beta$, and IL- 6 and anti-inflammatory cytokines IL-10 and TGF- $\beta$. Furthermore, chemokines IL-8, MIP-1a and MCP-1 were detected [45]. Furthermore, an in vivo study in neonatal Wistar rats demonstrated an increase in cytokines prior to BBB breakdown after induction of pneumococcal meningitis [105]. Entry of the CNS by the pneumococci is followed by rapid multiplication. Components released by the pathogen during this process are then recognized by PPRs resulting in a strong inflammatory response and subsequent BBB impairment [4].

\subsubsection{Group B streptococcus}

Group B streptococcus (GBS, Streptococcus agalactiae) is a $\beta$-haemolytic, gram-positive pathogen and the leading cause of meningitis in human neonates [106]. Classification of GBS strains is done by sequence type based on an allelic profile of seven loci [107]. The development of GBS meningitis is dependent on bloodstream survival and development of a high level of bacteremia of the pathogen, followed by the disruption of the BBB or possibly the BCSFB. This is followed by the multiplication of GBS in the CNS, culminating in severe inflammation and neural damage [4]. The necessity of high-level bacteremia indicates that bloodstream survival is an important virulence factor of the pathogen along with the sialylated GBS capsular polysaccharide [108]. Additionally, reduction of capsule expression by GBS was demonstrated to increase virulence and intracellular persistence [49]

Direct interaction of GBS with the BBB endothelium has been demonstrated, resulting in traversal of the barrier and subsequent infection of the CNS [49,109]. Both direct invasion of the BBB and/or brain invasion as a direct result of increased permeability of the barrier have been observed [4]. The use of in vitro models has further shown transcellular crossing of the pathogen [109]. To this end, a variety of virulence factors have been described. One of these factors is a surface anchored novel protein specific for the GBS ST-17 clone, which is associated with meningitis in infants after the first week of life, called hypervirulent GBS adhesin (HvgA) and is required for GBS hypervirulence. Increased adherence of strains expressing HvgA was detected for intestinal epithelial cells, choroid plexus epithelial cells, and microvascular endothelial cells of the BBB [110]. Another necessary determinant of the GBS interaction with the BBB is the expression of cell-wall anchored pili [111]. Interestingly, these pili displayed similar function in adhesion and invasion of GBS, given that the role of pili has been best described for gram-negative bacteria. Two proteins involved in the formation of the pili, encoded by pilA and pilB, were shown to facilitate the interaction with the BBB, wherein PilA is promoting attachment of GBS and PilB is mediating internalization of the bacterium [112]. Interaction of PilA with collagen promotes its interaction with the $\alpha_{2} \beta_{1}$ integrin, initiating the integrin signaling machinery [38]. Interaction 
with HBMECs is further enabled by the GBS fibronectin-binding protein streptococcal fibronectin binding protein A (SfbA) [113]. Additionally, GBS serine-rich repeat (Srr) glycoprotein was suggested to both promote bloodstream survival, facilitated by the adherence to fibrinogen, as well as adhesion to HBMECs [114]. An antigen I/II family adhesin, BspC, was recently demonstrated to interact with host cell vimentin during the pathogenesis of GBS meningitis, thereby promoting adherence of the pathogen in vitro as well as contributing to the development of GBS meningitis in vivo [115].

During invasion of type III GBS in HBMECs, tyrosine phosphorylation of the focal adhesion kinase (FAK) was demonstrated. Not only was the phosphorylation of the FAK required for invasion of GBS, it further induced association with PI3-kinase and paxillin, an actin filament adaptor protein [116]. BBB penetration of GBS was shown to also involve the invasion associated gene A (iagA). Mice challenged with a mutant version of this gene, encoding a glycosyltransferase homolog, developed bacteremia comparable to the wild type (WT) mice but had significantly lower mortality. In addition, the IagA gene encodes an enzyme, the glycolipid diglucosyldiacylglycerol, which functions as a cell membrane anchor for LTA, indicating that proper LTA anchoring is necessary for invasion of GBS into the BBB [117].

Similarly to S. pneumoniae, GBS can secrete a pore-forming toxin to disrupt barrier function in infected BMECs [109]. In addition, a further consequence of the interaction of PilA with $\alpha_{2} \beta_{1}$ integrin is the activation of host chemokine expression as well as neutrophil recruitment, which was correlated with increased permeability of the BBB [38]. Furthermore, GBS hyaluronidase HylB was demonstrated to induce BBB opening in a dose-dependent manner [118]. Another factor influencing BBB dysfunction was described during infection of induced pluripotent stem cell-derived brain endothelial cells with GBS, which resulted in the inhibition of P-glycoprotein, an important efflux transporter for the maintenance of brain homeostasis [119]. Barrier disruption and subsequent bacterial passage was further demonstrated to be promoted by reduced expression of tight junction components ZO-1, Claudin-5 and Occludin in HBMECs. This was facilitated by the induction of transcriptional repressor Snail1 and sufficient to promote tight junction disruption. This process, which was shown to be dependent on ERK 1/2 MAPK signaling as well as bacterial cell wall components, marks another mechanism of BBB disruption by GBS [120].

\subsection{Gram-Negative Bacteria}

\subsubsection{Escherichia coli}

E. coli, a gram-negative bacillary organism, is a common cause of meningitis and still an important cause of mortality and morbidity throughout the world. Circulating E. coli have been shown to traverse the BBB and the BCSFB as a result of hematogenous spread $[22,121]$. Expression of the K1 capsule and $O$-lipopolysaccharide are critical determinants of E. coli meningitis, especially in neonates [122-124]. Several factors have been demonstrated to influence $E$. coli invasion of the CNS such as a high level of bacteremia for the invasion of the blood-brain barrier, as well as a variety of virulence factors that initiate binding and translocation into the CNS [2].

The first step in E. coli invasion of the CNS is attachment to the cells of the brain barriers. The two major virulence factors associated with attachment to the blood-brain barrier are type 1 fimbriae and OmpA $[125,126]$. The virulence factor IbeA has been associated with the subsequent invasion process [127], as well as cytotoxic necrotizing factor 1 (CNF1) [128]. Deletion of ompA and ibeA reduced infection of choroid plexus epithelial cells in a human model of the BCSFB, whereas deletion of fimH enhanced invasion but simultaneously decreased adhesion of E. coli strains in the same model [121]. In an in vitro model of the BBB, Ecgp was identified as receptor for OmpA [129].

To promote internalization, E. coli induces rearrangements of the actin cytoskeleton. In HBMECs, this has been demonstrated to trigger a zipper-like mechanism that envelops the bacterium and initiates internalization into the cell. This process is dependent on both the actin cytoskeleton as well as microtubules [4]. Induction of tyrosine phosphorylation of FAK and cytoskeletal proteins by E. coli was demonstrated in an in vitro model of brain endothelial cells [130]. In addition, phosphatidylinositol 
3-kinase (PI3K) interaction with FAK and PI3-kinase signaling was shown to be necessary for successful invasion of E. coli in HBMECs [131]. In turn, PI3K activates phospholipase PLC $\gamma$, resulting in increased $\mathrm{Ca}^{2+}$ levels in the cells [132]. The cell adhesion molecule ICAM-1 was selectively upregulated during invasion of $E$. coli in brain endothelial cells through the interaction of OmpA and its receptor Ecgp. This upregulation was dependent on the previously described PI3K signaling pathways, as well as protein kinase $\mathrm{C}$ (PKC)- $\alpha$ and NK- $\mathrm{KB}$ signaling [133].

Traversal of E. coli across the BBB has been studied extensively using HBMECs as in vitro models [22]. Transmission electron microscopy revealed the pathogen crossing the HBMECs in membrane-bound vacuoles without intracellular replication [134]. Infection of HBMECs by E. coli $\mathrm{K} 1$ was further demonstrated to activate caveolin-1, resulting in the uptake of the pathogen via the caveolae. Furthermore, caveolin-1 interacts with phosphorylated protein kinase $C \alpha$ at the site of E. coli attachment [135]. To promote intracellular survival within the vacuoles, the E. coli K1 capsule is essential. It can modulate the maturation of the vacuoles and prevent fusion with lysosomes, thereby enabling traversal of live bacteria to the CNS [136]. There are gene clusters, essential for the production of the precursors that are the basis of the $\mathrm{K} 1$ capsule, called the neuDB genes. They were identified as an essential virulence factor promoting intracellular survival in HBMEC $[122,136]$. Furthermore, $n e u D B$ was also shown to be of importance during infection of an in vitro model of the BCSFB [121].

The breakdown of barrier function and neuroinflammation are considered key mechanisms in the invasion of the brain by pathogenic E. coli. In brain endothelial cells, upregulation of platelet-derived growth factor-B (PDGF-B) and ICAM-1 was demonstrated after infection with E. coli [137]. Further in vivo and in vitro studies suggest an involvement of PDGF-B in BBB permeability, mediating breakdown of tight junction proteins. Upregulation of ICAM-1 on the other hand was shown to initiate the inflammatory response of the CNS, mediating neutrophils or monocyte recruitment during infection [138]. The activation of PKC- $\alpha$ and its association with vascular-endothelial cadherins at the TJs of HBMECs resulted in increased cellular permeability and decrease in transendothelial electrical resistance by releasing $\beta$-catenin from the junctions. Notably, only E. coli strains expressing ompA could induce this increase in barrier permeability [139]. The infection of HBMECs with E. coli was further demonstrated to promote the production of nitric oxide (NO) by activating inducible nitric oxide synthase and, as a result, displayed enhanced invasion rates and increased permeability of HBMEC monolayers [140]. NO production was hypothesized to additionally be triggered by the modulation of pterin synthesis, which is involved in cell differentiation, pain modulation as well as mRNA stability. Infection of HBMECs was demonstrated to induce the rate-limiting enzyme in pterin synthesis, guanosine triphosphate cyclohydrolase (GCH1), indicating its role in the invasion process. GCH1 further interacts with Ecgp96, the receptor for OmpA [141]. These findings indicate an essential role for NO during E. coli invasion of the BBB. The response of HBMECs to meningitic and non-meningitic $E$. coli infections highlighted the role for macrophage migration inhibitory factor (MIF) during infection. MIF, a proinflammatory cytokine that has been described as a major factor during infection and septic shock, was demonstrated to have a role in BBB damage, as evidenced by the induction of a significant decrease in ZO-1 and occludin, as well as inflammation [142].

A further study described the role of E. coli $\mathrm{K} 1$ virulence factor $c g l D$ in polymorphonuclear leukocyte transendothelial migration [37]. A follow up analysis demonstrated a contribution of $c g l D$ to NF-KB pathway activation in HBMECs, promoting PMN adhesion and transendothelial migration across the BBB [143].

\subsubsection{Neisseria meningitidis}

Neisseria meningitidis (N. meningitidis) is a human-specific gram-negative bacterium. It can colonize the nasopharynx extracellularly and is often non-pathogenic and commensal. Some strains can cause life-threatening diseases such as meningitis. To reach the barriers protecting the CNS, N. meningitidis has to overcome the mucosal epithelium and enter the bloodstream. To survive in the bloodstream and subsequently enter the CNS, N. meningitidis utilizes different virulence factors. These protect the 
bacterium from being killed by the hosts complement system or other effectors. They include the polysaccharide capsule and other surface structures, such as pili and other adhesins [144]. Factor H-binding protein is another important factor for bloodstream survival and evading the host innate immune system by binding factor $\mathrm{H}$, which is a negative regulator of complement activation and alternative pathway and is bound to the surface of the pathogen $[145,146]$. N. meningitidis has been proposed to cross both the BBB and the BCSFB to the inner and the outer CSF [48,147-149].

The polysaccharide capsule of $N$. meningitidis is a major contributor to meningococcal disease and has been described as its main virulence factor. It can undergo genetic regulation and has the capability to mask the function of non-pilus adhesins [150]. While the capsule is essential for bloodstream survival, adhesion and invasion of host tissues are inhibited by the capsule [151]. Attenuated invasion was further described for capsulated strains of $N$. meningitidis in an in vitro model of the BCSFB [48]. The loss of the bacterial capsule for members of group $B$ and group $C$ meningococcal strains lead to increased uptake into HBMECs [152], and capsule and pili of N. meningitidis are downregulated upon contact with epithelial cells [153].

Adherence of $N$. meningitidis to host cells is facilitated by different virulence factors such as pili and surface exposed proteins like Opa and Opc, which further contribute to meningococcal disease. The type IV pili are a crucial adhesin expressed by N. meningitidis. They are involved in the attachment of capsulated virulence strains to host surfaces, extending from the bacterial surface through the capsule [154]. These long filamentous structures, made up of the major pilin protein and three minor pilins, promote adhesion of $N$. meningitidis to human endothelial cells via their interaction with CD147 [155]. In addition to the major pilin, type IV pili adhesion is also dependent on the expression of the outer membrane protein PilC [156-158]. Although affinity of pilin monomers to CD147 is weak, their assembly into the type IV pili as well as high expression of CD147 on the BBB supports the interaction [155]. Another group of adhesin-like structures, termed minor adhesion proteins, is expressed at low levels in vitro but may be of importance in in vivo environments which have been shown to alter the transcriptome of N. meningitidis [159].

While host, as well as tissue specificity, is determined by the pili and Opa proteins, invasion is facilitated by both Opa and Opc [160]. Opa proteins have been shown to bind to the carcinoembryonic antigen-related cellular adhesion molecule (CEACAM) receptor family, as well as the extracellular matrix proteins fibronectin and/or vitronectin [161,162]. An increase in adhesion and entry into HBMECs has been reported for N. meningitidis expressing Opc. This effect is facilitated by binding of Opc to serum vitronectin or fibronectin [163]. Also, activation of the acid sphingomyelidase/ceramide system, which involves clustering of ErbB2, an important receptor involved in bacterial uptake, by Opc-expressing N. meningitidis played a major role in determining the pathogens invasiveness [164]. Furthermore, the bacterial adhesins PilQ and PorA were shown to bind to the laminin receptor, thereby initiating contact with the BBB [99].

Attachment and invasion of human cells by three hypervirulent serogroup B strains of N. meningitidis is furthermore promoted by the Neisseria adhesin A (NadA), a phase-variable, surface-exposed protein [165-167]. For its interaction with the host, different membrane proteins have been suggested. NadA was shown to target human $\beta 1$ integrin subunits [150]. Also, a genome-wide microarray analysis provided evidence for an interaction between NadA and the endothelial low-density oxidized lipoprotein receptor 1 (LOX-1) [168]. Following initial binding to the cell surface, the formation of microcolonies was observed, which in turn promoted the formation of specific molecular complexes called "cortical plaques". These structures contain accumulated ezrin, moesin, tyrosine-phosphorylated proteins, ICAM-1/-2, CD44 and epidermal growth factor receptors (EGFR) as well as localized polymerized cortical actin, resulting in major reorganization of host cell morphology. Changes in cell surface morphology are a prerequisite for bacterial uptake and the formation of microvilli-like cellular projections which protect the microcolonies from shear stress of the bloodstream [169]. 
Following attachment, N. meningitidis induces host cell signaling events to facilitate invasion into host tissues. These include the recruitment of ezrin as well as the activation of Src kinase and cortactin [170-172]. Furthermore, the FAK is essential for integrin-mediated internalization of N. meningitidis in HBMECs, enabling endocytosis through the interplay between FAK, Src and cortactin. This is facilitated by N. meningitidis using the integrin signaling pathways to mediate signaling from activated integrins upon attachment to the cytoskeleton [173]. These events promote the reorganization of the actin cytoskeleton resulting in the formation of membrane protrusions that take up the pathogens by surrounding them for internalization [144]. Genes involved in cytoskeletal reorganization were shown to be differentially expressed after infection of HBMECs [174]. Analysis of whole-cell lysates of human endothelial and epithelial cells have revealed an interaction of the Opc protein with alpha actinin, a modulator of various signaling pathways and cytoskeletal functions [175].

Disruption of the BBB integrity was observed in in vitro studies as a consequence of opening intracellular junctions [176]. Furthermore, cell detachment is initiated through activation of MMP 8, promoting cleavage of the TJ protein occludin [177]. Alterations of intracellular junctions were observed in a human brain microvascular endothelial cell line, potentially opening up a paracellular route of crossing the BBB into the CNS through recruitment of the Par3/Par6/PKC $\zeta$ polarity complex [178].

Meningococcal disease is accompanied by an acute inflammatory response [179]. The transcription factor (TF) NF- $\mathrm{KB}$, associated with the release of proinflammatory cytokines and chemokines during the inflammatory response, was shown to be active in an in vitro CP epithelial model after infection with N. meningitidis. Its activation was believed to arise from heterodimerization of TLR2 and TLR6 [33]. In HBMEC the p38 MAPK had an impact on the release of IL-6 and IL-8, whereas the c-JUN N-terminal kinases 1 and 2 (JNK1 and JNK2) were important for invasion [180].

\subsubsection{Haemophilus influenzae}

Haemophilus influenzae (H. influenzae) is a gram-negative bacterium capable of colonizing the upper respiratory tract. The makeup of the polysaccharide capsule determines the pathogens classification into serotypes a to f, of which $\mathrm{H}$. influenzae serotype $\mathrm{b}(\mathrm{Hib})$ is responsible for the most severe infections, such as meningitis, especially in children under the age of 5 years [181]. Although there is widespread vaccination against $H i b$, some populations remain vulnerable and the vaccines do not protect against other serotypes [182]. Furthermore, in areas where Hib vaccines are used, nontypeable H. influenzae (NTHi) strains can now be the most common cause of meningitis [183]. Similar to the before described pathogens, $H$. influenzae has to cross the epithelial barrier of the upper respiratory tract and, after dissemination and survival in the bloodstream, cross the barriers of the brain to enter the CNS [184]. Traversal of both the BBB and BCSFB has been demonstrated for H. influenzae [47,51].

Attachment to host cells is enabled by the bacterial capsule and fimbriae which are subject to reversible phase variation [185]. H. influenzae shares a common strategy to enter endothelial cells with S. pneumoniae and N. meningitidis, which involves binding to the PAFR, mediated by phosphorylcholine (ChoP) $[186,187]$. This interaction results in the entry of the pathogens into the BBB through activation of $\beta$-arrestin-mediated uptake [188]. Binding of PAFR by lipooligosaccharide (LOS) glycoforms containing ChoP was also demonstrated during invasion NTHi. This binding resulted in the activation of host cell signaling by coupling with pertussis toxin-sensitive (PTX) heterotrimeric G protein complexes and invasion of the pathogen. It was further suggested that this mechanism was more efficient than micropinocytosis [187]. Binding to laminin receptor, another shared mechanism of these pathogens, is initiated by OmpP2, facilitating the interaction with the brain endothelium by H. influenzae [99].

In an in vitro model of the BCSFB, Hib as well as clinical isolates of Hib and H. influenzae serotype $\mathrm{f}(\mathrm{Hif})$ were shown to adhere and invade the HIBCPP cells as intracellular bacteria. Both fimbriae and the capsule lead to attenuated invasion [47]. Also, a study using H. influenzae serotype a (Hia) and a co-culture of HBMECs and pericytes demonstrated an activation of stimulated $\mathrm{A}_{2 \mathrm{~A}}$ and $\mathrm{A}_{2 \mathrm{~B}}$ adenosine receptors after infection. This in turn led to the release of Vascular Endothelial Growth Factor (VEGF) 
by the pericytes leading to pericyte detachment and endothelial cell proliferation resulting in overall BBB impairment [189].

Using rat models of meningitis, a dose-dependent increase of BBB permeability was observed after inoculation with Hib LPS [190]. Later studies showed that the permeability of the BBB was also increased in rats after inoculation with $H$. influenzae outer membrane vesicles (OMV), suggesting a role for these vesicles in transporting Hib LPS to the CSF during meningitis [191]. Furthermore, it was shown that zyxin, a cytoskeletal protein implicated in the protection of TJs in the BBB, is critical for the integrity of the BBB and, as a consequence, for protecting against invading pathogens such as H. influenzae [192]. Overall, the inflammatory response of patients during the infection with H. influenzae is determined by several virulence factors including the capsule, adhesion proteins, pili and outer membrane proteins as well as LPS and IgA1 protease [193]. 
Table 1. Evidence for the involvement of gram-positive and gram-negative bacteria during brain entry at the BBB and BCSFB.

\begin{tabular}{|c|c|c|c|c|}
\hline \multirow{2}{*}{$\begin{array}{c}\text { Pathogen } \\
\text { Gram-Positive }\end{array}$} & \multirow{2}{*}{$\begin{array}{c}\text { Entry Mechanisms } \\
\text { BBB }\end{array}$} & \multicolumn{3}{|c|}{ Major Virulence Factors } \\
\hline & & BCSFB & BBB & BCSFB \\
\hline L. monocytogenes & $\begin{array}{l}\text { Transcellular route [54] } \\
\text { "Trojan horse" mechanism } \\
\text { within leukocytes [54] } \\
\text { Retrograde migration within } \\
\text { axons of cranial nerves [54] }\end{array}$ & Transcellular route [57] & $\begin{array}{l}\text { Major invasion protein InlB } \\
\text { inducing receptor-mediated } \\
\text { endocytosis [25] } \\
\text { Bacterial surface protein InlF } \\
\text { interacting with surface } \\
\text { vimentin [58] } \\
\text { Pore-forming cytolysin LLO } \\
\text { inducing signaling pathways } \\
\text { (NF-kB, MAPK) [64,66] } \\
\text { ActA promoting F-actin-based } \\
\text { intracellular motility [68] }\end{array}$ & $\begin{array}{c}\text { Major invasion proteins InlA } \\
\text { and InlB inducing } \\
\text { receptor-mediated endocytosis } \\
{[34,57]}\end{array}$ \\
\hline S. suis & $\begin{array}{l}\text { Invasion at low rates in porcine } \\
\text { models }[73,78] .\end{array}$ & $\begin{array}{c}\text { Invasion demonstrated for } \\
\text { porcine and human in vitro } \\
\text { models [48,72] } \\
\text { Possibly “Trojan-horse" } \\
\text { mechanism [85] }\end{array}$ & $\begin{array}{c}\text { Enolase increasing BBB } \\
\text { permeability [80] } \\
\text { Suilysin inducing pore } \\
\text { formation in membranes [81] }\end{array}$ & $\begin{array}{l}\text { Regulation of capsule } \\
\text { expression }[48,72]\end{array}$ \\
\hline S. pneumoniae & $\begin{array}{c}\text { Translocation across BBB } \\
\text { in vivo and in vitro }[87,194]\end{array}$ & $\begin{array}{l}\text { Only attachment observed in an } \\
\text { in vivo mouse model during } \\
\text { late stages of infection with high } \\
\text { levels of bacteremia [87]. }\end{array}$ & $\begin{array}{c}\text { Altered expression of the } \\
\text { capsule for attachment }[92,93] \\
\text { Interaction with BBB through } \\
\text { NadA [96] } \\
\text { Pore-forming toxin } \\
\text { pneumolysin [101] }\end{array}$ & \\
\hline GBS & $\begin{array}{c}\text { Traversal of BBB in vivo and } \\
\text { in vitro }[49,109,195]\end{array}$ & & $\begin{array}{c}\text { Expression of cell-wall } \\
\text { anchored pili [111] } \\
\text { PilA: promoting attachment of } \\
\text { GBS [112] } \\
\text { PilB: mediating internalization } \\
\text { [112] }\end{array}$ & \\
\hline
\end{tabular}


Table 1. Cont.

\begin{tabular}{|c|c|c|c|c|}
\hline Pathogen & Entry Mechanisms & & Major Virulence Factors & \\
\hline Gram-Negative & BBB & BCSFB & BBB & BCSFB \\
\hline E. coli & $\begin{array}{c}\text { Traversal of BBB in vivo and } \\
\text { in vitro [22] }\end{array}$ & $\begin{array}{c}\text { Traversal of BCSFB in vitro } \\
{[121]}\end{array}$ & $\begin{array}{c}\text { Attachent facilitated by type } 1 \\
\text { fimbriae and OmpA [125,126] } \\
\text { Invasion induced by IbeA [127] } \\
\text { and CNF1 [128] } \\
\text { Intracellular survival promoted } \\
\text { by the E. coli K1 capsule [136] }\end{array}$ & $\begin{array}{c}\text { Role of fimH during adhesion } \\
\text { [121] } \\
\text { Involvement of OmpA, FimH } \\
\text { and IbeA in invasion [121] }\end{array}$ \\
\hline N. meningitidi & $\begin{array}{c}\text { Traversal of BBB in vivo and } \\
\text { in vitro }[2,196]\end{array}$ & $\begin{array}{c}\text { Traversal of BCSFB in vitro of } \\
\text { choroid plexus epithelial cells } \\
\text { [48] } \\
\text { Invasion of outer BCSFB in } \\
\text { induced pluripotent stem } \\
\text { cell-derived brain endothelial } \\
\text { cells [149] }\end{array}$ & $\begin{array}{l}\text { Protective function of the } \\
\text { polysaccharide capsule during } \\
\text { bloodstream survival but } \\
\text { attenuated tissue invasion [151] } \\
\text { Adherence through pili and } \\
\text { surface exposed proteins [154] } \\
\text { Invasion is facilitated by Opa } \\
\text { and Opc [160] }\end{array}$ & $\begin{array}{l}\text { Capsule attenuates invasion } \\
\text { in vitro [48] }\end{array}$ \\
\hline H. influenzae & Traversal of BBB in vitro [51] & Traversal of BCSFB in vitro [47] & $\begin{array}{c}\text { Entry via binding of PAFR } \\
{[186,187]} \\
\text { Attachment facilitated by } \\
\text { binding of the laminin receptor } \\
{[99]}\end{array}$ & $\begin{array}{c}\text { Capsule and fimbriae attenuate } \\
\text { invasion [47] } \\
\text { Invasion if } H \text {. influenzae was } \\
\text { observed as intracellular } \\
\text { bacterium [47] }\end{array}$ \\
\hline
\end{tabular}




\section{Conclusions}

A variety of studies have focused on how pathogens cross the blood-CNS barriers, mostly focusing on the BBB. Although significant progress has been made in identifying mechanisms of host-pathogen interactions during bacterial meningitis, additional efforts towards identifying bacterial and host cell targets are needed. The diversity of mechanisms used by these pathogens presents the need for further research. To this end, the identification of common mechanisms used by multiple pathogens will be of great significance and further assist the development of effective therapies. Of high importance is the distinction between the mechanisms the pathogens use for crossing the BCSFB and the BBB. Pathogens exploiting epitopes of both barriers would present interesting targets for the development of therapeutics.

Author Contributions: Conceptualization, R.H. and C.S.; writing-original draft preparation, R.H.; writing - review and editing, H.S. and C.S.

Funding: This research received no external funding.

Acknowledgments: We acknowledge financial support by Deutsche Forschungsgemeinschaft within the funding programme Open Access Publishing, by the Baden-Württemberg Ministry of Science, Research and the Arts and by Ruprecht-Karls-Universität Heidelberg.

Conflicts of Interest: The authors declare no conflict of interest

\section{Abbreviations}

$\begin{array}{ll}\text { ABC } & \text { ATP-binding cassette } \\ \text { BBB } & \text { Blood-brain barrier } \\ \text { BCSFB } & \text { Blood-cerebrospinal fluid barrier } \\ \text { BMEC } & \text { Brain microvascular endothelial cells } \\ \text { CBP } & \text { CERB-binding protein } \\ \text { CbpA } & \text { Choline-binding protein A } \\ \text { CECAM } & \text { Carcinoembryonic antigen-related cellular adhesion molecule } \\ \text { ChoP } & \text { Phosphorylcholine } \\ \text { CNF1 } & \text { Cytotoxic necrotizing factor 1 } \\ \text { CNS } & \text { Central nervous system } \\ \text { CP } & \text { Choroid plexus } \\ \text { EGFR } & \text { Epidermal growth factor receptors } \\ \text { ERK } & \text { Extracellular signal-regulated kinases } \\ \text { FAK } & \text { Focal adhesion kinase } \\ \text { GCH1 } & \text { Guanosine triphosphate cyclohydrolase } \\ \text { GlpO } & \alpha \text {-glycerophosphate oxidase } \\ \text { HBMECs } & \text { Human brain microvascular endothelial cells } \\ \text { HIBCPP } & \text { Human choroid plexus epithelial papilloma } \\ \text { HvgA } & \text { Hypervirulent GBS adhesin } \\ \text { iagA } & \text { invasion associated gene A } \\ \text { Inl } & \text { Internalin } \\ \text { JNK } & \text { c-JUN N-terminal kinases } \\ \text { LLO } & \text { Listeriolysin O } \\ \text { LOS } & \text { Lipooligosaccharide } \\ \text { LOX 1 } & \text { Lipoprotein receptor 1 } \\ \text { LPS } & \text { Lipopolysaccharide } \\ \text { LTA } & \text { Lipoteichoic acid } \\ \text { MAPK } & \text { Mitogen activated protein kinase } \\ \text { MIF } & \text { Macrophage migration inhibitory factor } \\ \text { MMP } & \text { Matrix metalloproteinase } \\ & \end{array}$




$\begin{array}{ll}\text { Nad A } & \text { Neuraminidase A } \\ \text { NadA } & \text { Neisseria adhesin A } \\ \text { NF-kB } & \text { Nuclear factor } \mathrm{kB} \\ \text { NO } & \text { Nitric oxide } \\ \text { NOD2 } & \text { Nucleotide-binding oligomerization domain 2 } \\ \text { OMV } & \text { Outer membrane vesicles } \\ \text { PAFR } & \text { Platelet-activating factor receptor } \\ \text { PAMPs } & \text { Pathogen-associated molecular patterns } \\ \text { PCPEC } & \text { Primary porcine CP epithelial cells } \\ \text { PDGF-B } & \text { Platelet-derived growth factor-B } \\ \text { PECAM } & \text { Platelet endothelial cell adhesion molecule } \\ \text { PI3K } & \text { Phosphatidylinositol 3-kinase } \\ \text { PKC } & \text { Protein kinase C } \\ \text { plgR } & \text { Polymeric immunoglobulin receptor } \\ \text { PMN } & \text { Polymorphnuclear neutrophils } \\ \text { PPRs } & \text { Pattern recognition receptors } \\ \text { PTX } & \text { Pertussis toxin-sensitive } \\ \text { Ssr } & \text { Serine-rich repeat } \\ \text { T3SS } & \text { Type three secretion system } \\ \text { TF } & \text { Transcription factor } \\ \text { TGF- } \beta & \text { Transforming growth factor- } \beta \\ \text { TJs } & \text { Tight junctions } \\ \text { TNF } & \text { Tumor necrosis factor } \\ \text { VEGF } & \text { Vascular Endothelial Growth Factor } \\ \text { GBS } & \text { Group B streptococcus, Streptococcus agalactiae } \\ \text { E. coli } & \text { Escherichia coli } \\ \text { H. influenzae } & \text { Haemophilus influenzae } \\ \text { Hia } & \text { H. influenzae serotype a } \\ \text { Hib } & \text { H. influenzae serotype b } \\ \text { Hif } & \text { H. influenzae serotype f } \\ \text { L. monocytogenes } & \text { Listeria monocytogenes } \\ \text { N. meningitidis } & \text { Neisseria meningitidis } \\ \text { NTHi } & \text { nontypeable H. influenzae } \\ \text { S. pneumoniae } & \text { Streptoccus pneumoniae } \\ \text { S. suis } & \text { Strects } \\ & \end{array}$

\section{References}

1. Dando, S.J.; Mackay-Sim, A.; Norton, R.; Currie, B.J.; St John, J.A.; Ekberg, J.A.K.; Batzloff, M.; Ulett, G.C.; Beacham, I.R. Pathogens penetrating the central nervous system: Infection pathways and the cellular and molecular mechanisms of invasion. Clin. Microbiol. Rev. 2014, 27, 691-726. [CrossRef] [PubMed]

2. Kim, K.S. Mechanisms of microbial traversal of the blood-brain barrier. Nat. Rev. Microbiol. 2008, 6, 625-634. [CrossRef] [PubMed]

3. Wolburg, H.; Paulus, W. Choroid plexus: Biology and pathology. Acta Neuropathol. 2010, 119, 75-88.

4. Doran, K.S.; Fulde, M.; Gratz, N.; Kim, B.J.; Nau, R.; Prasadarao, N.; Schubert-Unkmeir, A.; Tuomanen, E.I.; Valentin-Weigand, P. Host-pathogen interactions in bacterial meningitis. Acta Neuropathol. 2016, 131, 185-209. [CrossRef] [PubMed]

5. Marques, F.; Sousa, J.C.; Sousa, N.; Palha, J.A. Blood-brain-barriers in aging and in alzheimer's disease. Mol. Neurodegener. 2013, 8, 38 .

6. Saunders, N.R.; Habgood, M.D.; Mollgard, K.; Dziegielewska, K.M. The biological significance of brain barrier mechanisms: Help or hindrance in drug delivery to the central nervous system? F1000Res. 2016, 5. [CrossRef]

7. Lauer, A.N.; Tenenbaum, T.; Schroten, H.; Schwerk, C. The diverse cellular responses of the choroid plexus during infection of the central nervous system. Am. J. Physiol. Cell Physiol. 2018, 314, C152-C165. 
8. Van Sorge, N.M.; Doran, K.S. Defense at the border: The blood-brain barrier versus bacterial foreigners. Future Microbiol. 2012, 7, 383-394.

9. Daneman, R.; Prat, A. The blood-brain barrier. Cold Spring Harb. Perspect. Biol. 2015, 7. [CrossRef]

10. Abbott, N.J.; Patabendige, A.A.K.; Dolman, D.E.M.; Yusof, S.R.; Begley, D.J. Structure and function of the blood-brain barrier. Neurobiol. Dis. 2010, 37, 13-25. [CrossRef]

11. Dias, M.C.; Coisne, C.; Lazarevic, I.; Baden, P.; Hata, M.; Iwamoto, N.; Francisco, D.M.F.; Vanlandewijck, M.; He, L.Q.; Baier, F.A.; et al. Claudin-3-deficient c57bl/6j mice display intact brain barriers. Sci. Rep. 2019, 9, 203. [CrossRef] [PubMed]

12. Tietz, S.; Engelhardt, B. Brain barriers: Crosstalk between complex tight junctions and adherens junctions. J. Cell Biol. 2015, 209, 493-506. [CrossRef] [PubMed]

13. Hawkins, R.A.; O'Kane, R.L.; Simpson, I.A.; Vina, J.R. Structure of the blood-brain barrier and its role in the transport of amino acids. J. Nutr. 2006, 136, 218s-226s. [CrossRef] [PubMed]

14. Sweeney, M.D.; Zhao, Z.; Montagne, A.; Nelson, A.R.; Zlokovic, B.V. Blood-brain barrier: From physiology to disease and back. Physiol. Rev. 2019, 99, 21-78. [CrossRef]

15. Weller, R.O.; Sharp, M.M.; Christodoulides, M.; Carare, R.O.; Mollgard, K. The meninges as barriers and facilitators for the movement of fluid, cells and pathogens related to the rodent and human cns. Acta Neuropathol. 2018, 135, 363-385. [CrossRef]

16. Liddelow, S.A. Development of the choroid plexus and blood-csf barrier. Front. Neurosci. 2015, 9. [CrossRef]

17. Schwerk, C.; Tenenbaum, T.; Kim, K.S.; Schroten, H. The choroid plexus-a multi-role player during infectious diseases of the cns. Front. Cell. Neurosci. 2015, 9. [CrossRef]

18. Bernd, A.; Ott, M.; Ishikawa, H.; Schroten, H.; Schwerk, C.; Fricker, G. Characterization of efflux transport proteins of the human choroid plexus papilloma cell line hibcpp, a functional in vitro model of the blood-cerebrospinal fluid barrier. Pharm. Res. 2015, 32, 2973-2982. [CrossRef]

19. Ransohoff, R.M.; Engelhardt, B. The anatomical and cellular basis of immune surveillance in the central nervous system. Nat. Rev. Immunol. 2012, 12, 623-635. [CrossRef]

20. Sullivan, T.D.; Lascolea, L.J.; Neter, E. Relationship between the magnitude of bacteremia in children and the clinical-disease. Pediatrics 1982, 69, 699-702.

21. Dietzman, D.E.; Fischer, G.W.; Schoenknecht, F.D. Neonatal escherichia coli septicemia-bacterial counts in blood. J. Pediatr. 1974, 85, 128-130. [CrossRef]

22. Kim, K.S. Human meningitis-associated escherichia coli. Ecosal Plus 2016, 7. [CrossRef] [PubMed]

23. Bell, L.M.; Alpert, G.; Campos, J.M.; Plotkin, S.A. Routine quantitative blood cultures in children with haemophilus influenzae or streptococcus pneumoniae bacteremia. Pediatrics 1985, 76, 901-904. [PubMed]

24. Virji, M. Ins and outs of microbial adhesion. Top. Curr. Chem. 2009, 288, 139-156. [PubMed]

25. Cossart, P.; Helenius, A. Endocytosis of viruses and bacteria. Cold Spring Harb. Perspect. Biol. 2014, 6, a016972. [CrossRef] [PubMed]

26. Cossart, P.; Sansonetti, P.J. Bacterial invasion: The paradigms of enteroinvasive pathogens. Science 2004, 304, 242-248. [CrossRef] [PubMed]

27. Mota, L.J.; Cornelis, G.R. The bacterial injection kit: Type iii secretion systems. Ann. Med. 2005, 37, $234-249$. [CrossRef] [PubMed]

28. Santiago-Tirado, F.H.; Doering, T.L. False friends: Phagocytes as trojan horses in microbial brain infections. PLoS Path. 2017, 13, e1006680. [CrossRef]

29. Selbach, M.; Backert, S. Cortactin: An achilles' heel of the actin cytoskeleton targeted by pathogens. Trends Microbiol. 2005, 13, 181-189. [CrossRef]

30. Stradal, T.E.B.; Schelhaas, M. Actin dynamics in host-pathogen interaction. Febs Lett. 2018, 592, 3658-3669. [CrossRef]

31. Frischknecht, F.; Way, M. Surfing pathogens and the lessons learned for actin polymerization. Trends Cell Biol. 2001, 11, 30-38. [CrossRef]

32. Lamason, R.L.; Welch, M.D. Actin-based motility and cell-to-cell spread of bacterial pathogens. Curr. Opin. Microbiol. 2017, 35, 48-57. [CrossRef] [PubMed]

33. Borkowski, J.; Li, L.; Steinmann, U.; Quednau, N.; Stump-Guthier, C.; Weiss, C.; Findeisen, P.; Gretz, N.; Ishikawa, H.; Tenenbaum, T.; et al. Neisseria meningitidis elicits a pro-inflammatory response involving ikappabzeta in a human blood-cerebrospinal fluid barrier model. J. Neuroinflammation 2014, 11, 163. [CrossRef] [PubMed] 
34. Dinner, S.; Kaltschmidt, J.; Stump-Guthier, C.; Hetjens, S.; Ishikawa, H.; Tenenbaum, T.; Schroten, H.; Schwerk, C. Mitogen-activated protein kinases are required for effective infection of human choroid plexus epithelial cells by listeria monocytogenes. Microbes Infect. 2017, 19, 18-33. [CrossRef] [PubMed]

35. Krachler, A.M.; Woolery, A.R.; Orth, K. Manipulation of kinase signaling by bacterial pathogens. J. Cell Biol. 2011, 195, 1083-1092. [CrossRef] [PubMed]

36. Pizarro-Cerda, J.; Cossart, P. Bacterial adhesion and entry into host cells. Cell 2006, 124, 715-727. [CrossRef] [PubMed]

37. Wang, S.; Peng, L.; Gai, Z.; Zhang, L.; Jong, A.; Cao, H.; Huang, S.H. Pathogenic triad in bacterial meningitis: Pathogen invasion, nf-kappab activation, and leukocyte transmigration that occur at the blood-brain barrier. Front. Microbiol 2016, 7, 148. [CrossRef]

38. Banerjee, A.; Kim, B.J.; Carmona, E.M.; Cutting, A.S.; Gurney, M.A.; Carlos, C.; Feuer, R.; Prasadarao, N.V.; Doran, K.S. Bacterial pili exploit integrin machinery to promote immune activation and efficient blood-brain barrier penetration. Nat. Commun. 2011, 2, 462. [CrossRef]

39. Koedel, U.; Scheld, W.M.; Pfister, H.W. Pathogenesis and pathophysiology of pneumococcal meningitis. Lancet Infect. Dis. 2002, 2, 721-736. [CrossRef]

40. Kim, S.Y.; Buckwalter, M.; Soreq, H.; Vezzani, A.; Kaufer, D. Blood-brain barrier dysfunction-induced inflammatory signaling in brain pathology and epileptogenesis. Epilepsia 2012, 53, 37-44. [CrossRef]

41. Haberl, R.L.; Anneser, F.; Kodel, U.; Pfister, H.W. Is nitric-oxide involved as a mediator of cerebrovascular changes in the early phase of experimental pneumococcal meningitis. Neurol. Res. 1994, 16, 108-112. [CrossRef] [PubMed]

42. Leppert, D.; Leib, S.L.; Grygar, C.; Miller, K.M.; Schaad, U.B.; Hollander, G.A. Matrix metalloproteinase (mmp)-8 and mmp-9 in cerebrospinal fluid during bacterial meningitis: Association with blood-brain barrier damage and neurological sequelae. Clin. Infect. Dis. 2000, 31, 80-84. [CrossRef] [PubMed]

43. Zwijnenburg, P.J.; de Bie, H.M.; Roord, J.J.; van der Poll, T.; van Furth, A.M. Chemotactic activity of cxcl5 in cerebrospinal fluid of children with bacterial meningitis. J. Neuroimmunol. 2003, 145, 148-153. [CrossRef] [PubMed]

44. Azuma, H.; Tsuda, N.; Sasaki, K.; Okuno, A. Clinical significance of cytokine measurement for detection of meningitis. J. Pediatr 1997, 131, 463-465. [CrossRef]

45. Coutinho, L.G.; Grandgirard, D.; Leib, S.L.; Agnez-Lima, L.F. Cerebrospinal-fluid cytokine and chemokine profile in patients with pneumococcal and meningococcal meningitis. BMC Infect. Dis. 2013, 13, 326. [CrossRef]

46. Cress, B.F.; Englaender, J.A.; He, W.Q.; Kasper, D.; Linhardt, R.J.; Koffas, M.A.G. Masquerading microbial pathogens: Capsular polysaccharides mimic host-tissue molecules. Fems Microbiol. Rev. 2014, 38, 660-697. [CrossRef]

47. Hauser, S.; Wegele, C.; Stump-Guthier, C.; Borkowski, J.; Weiss, C.; Rohde, M.; Ishikawa, H.; Schroten, H.; Schwerk, C.; Adam, R. Capsule and fimbriae modulate the invasion of haemophilus influenzae in a human blood-cerebrospinal fluid barrier model. Int. J. Med. Microbiol. 2018, 308, 829-839. [CrossRef]

48. Schwerk, C.; Papandreou, T.; Schuhmann, D.; Nickol, L.; Borkowski, J.; Steinmann, U.; Quednau, N.; Stump, C.; Weiss, C.; Berger, J.; et al. Polar invasion and translocation of neisseria meningitidis and streptococcus suis in a novel human model of the blood-cerebrospinal fluid barrier. PLOS ONE 2012, 7, e30069. [CrossRef]

49. Gendrin, C.; Merillat, S.; Vornhagen, J.; Coleman, M.; Armistead, B.; Ngo, L.; Aggarwal, A.; Quach, P.; Berrigan, J.; Rajagopal, L. Diminished capsule exacerbates virulence, blood-brain barrier penetration, intracellular persistence, and antibiotic evasion of hyperhemolytic group b streptococci. J. Infect. Dis. 2018, 217, 1128-1138. [CrossRef]

50. Wu, Z.F.; Wu, C.Y.; Shao, J.; Zhu, Z.Z.; Wang, W.X.; Zhang, W.W.; Tang, M.; Pei, N.; Fan, H.J.; Li, J.G.; et al. The streptococcus suis transcriptional landscape reveals adaptation mechanisms in pig blood and cerebrospinal fluid. RNA 2014, 20, 882-898. [CrossRef]

51. Al-Obaidi, M.M.J.; Desa, M.N.M. Mechanisms of blood brain barrier disruption by different types of bacteria, and bacterial-host interactions facilitate the bacterial pathogen invading the brain. Cell. Mol. Neurobiol. 2018, 38, 1349-1368. [CrossRef] [PubMed]

52. Disson, O.; Lecuit, M. Targeting of the central nervous system by listeria monocytogenes. Virulence 2012, 3, 213-221. [CrossRef] [PubMed] 
53. Radoshevich, L.; Cossart, P. Listeria monocytogenes: Towards a complete picture of its physiology and pathogenesis. Nat. Rev. Microbiol. 2018, 16, 32-46. [CrossRef] [PubMed]

54. Drevets, D.A.; Leenen, P.J.M.; Greenfield, R.A. Invasion of the central nervous system by intracellular bacteria. Clin. Microbiol. Rev. 2004, 17, 323-347. [CrossRef] [PubMed]

55. Pagelow, D.; Chhatbar, C.; Beineke, A.; Liu, X.K.; Nerlich, A.; van Vorst, K.; Rohde, M.; Kalinke, U.; Forster, R.; Halle, S.; et al. The olfactory epithelium as a port of entry in neonatal neurolisteriosis. Nat. Commun. 2018, 9, 4269. [CrossRef] [PubMed]

56. Greiffenberg, L.; Goebel, W.; Kim, K.S.; Daniels, J.; Kuhn, M. Interaction of listeria monocytogenes with human brain microvascular endothelial cells: An electron microscopic study. Infect. Immun. 2000, 68, 3275-3279. [CrossRef]

57. Grundler, T.; Quednau, N.; Stump, C.; Orian-Rousseau, V.; Ishikawa, H.; Wolburg, H.; Schroten, H.; Tenenbaum, T.; Schwerk, C. The surface proteins inla and inlb are interdependently required for polar basolateral invasion by listeria monocytogenes in a human model of the blood-cerebrospinal fluid barrier. Microbes Infect. 2013, 15, 291-301. [CrossRef]

58. Ghosh, P.; Halvorsen, E.M.; Ammendolia, D.A.; Mor-Vaknin, N.; O’Riordan, M.X.D.; Brumell, J.H.; Markovitz, D.M.; Higgins, D.E. Invasion of the brain by listeria monocytogenes is mediated by inlf and host cell vimentin. MBio 2018, 9. [CrossRef]

59. Tang, P.; Rosenshine, I.; Finlay, B.B. Listeria-monocytogenes, an invasive bacterium, stimulates map kinase upon attachment to epithelial-cells. Mol. Biol. Cell 1994, 5, 455-464. [CrossRef]

60. Tang, P.; Sutherland, C.L.; Gold, M.R.; Finlay, B.B. Listeria monocytogenes invasion of epithelial cells requires the mek-1/erk-2 mitogen-activated protein kinase pathway. Infect. Immun. 1998, 66, 1106-1112.

61. Pizarro-Cerda, J.; Kuhbacher, A.; Cossart, P. Entry of listeria monocytogenes in mammalian epithelial cells: An updated view. Cold Spring Harb. Perspect. Med. 2012, 2, a010009. [CrossRef] [PubMed]

62. Veiga, E.; Cossart, P. Listeria hijacks the clathrin-dependent endocytic machinery to invade mammalian cells. Nat. Cell Biol. 2005, 7. [CrossRef] [PubMed]

63. Veiga, E.; Guttman, J.A.; Bonazzi, M.; Boucrot, E.; Toledo-Arana, A.; Lin, A.E.; Enninga, J.; Pizarro-Cerda, J.; Finlay, B.B.; Kirchhausen, T.; et al. Invasive and adherent bacterial pathogens co-opt host clathrin for infection. Cell Host Microbe 2007, 2, 340-351. [CrossRef] [PubMed]

64. Kayal, S.; Lilienbaum, A.; Join-Lambert, O.; Li, X.X.; Israel, A.; Berche, P. Listeriolysin o secreted by listeria monocytogenes induces nf-kappa $\mathrm{b}$ signalling by activating the i kappa b kinase complex. Mol. Microbiol. 2002, 44, 1407-1419. [CrossRef]

65. Tang, P.; Rosenshine, I.; Cossart, P.; Finlay, B.B. Listeriolysin o activates mitogen-activated protein kinase in eucaryotic cells. Infect. Immun. 1996, 64, 2359-2361.

66. Weiglein, I.; Goebel, W.; Troppmair, J.; Rapp, U.R.; Demuth, A.; Kuhn, M. Listeria monocytogenes infection of hela cells results in listeriolysin o-mediated transient activation of the raf-mek-map kinase pathway. Fems Microbiol. Lett. 1997, 148, 189-195. [CrossRef]

67. Lambrechts, A.; Gevaert, K.; Cossart, P.; Vandekerckhove, J.; Van Troys, M. Listeria comet tails: The actin-based motility machinery at work. Trends Cell Biol. 2008, 18, 220-227. [CrossRef]

68. Kocks, C.; Gouin, E.; Tabouret, M.; Berche, P.; Ohayon, H.; Cossart, P. L-monocytogenes-induced actin assembly requires the acta gene-product, a surface protein. Cell 1992, 68, 521-531. [CrossRef]

69. Gouin, E.; Adib-Conquy, M.; Balestrino, D.; Nahori, M.A.; Villiers, V.; Colland, F.; Dramsi, S.; Dussurget, O.; Cossart, P. The listeria monocytogenes inlc protein interferes with innate immune responses by targeting the i kappa b kinase subunit ikk alpha. Proc. Natl. Acad. Sci. USA 2010, 107, 17333-17338. [CrossRef]

70. Rajabian, T.; Gavicherla, B.; Heisig, M.; Muller-Altrock, S.; Goebel, W.; Gray-Owen, S.D.; Ireton, K. The bacterial virulence factor inlc perturbs apical cell junctions and promotes cell-to-cell spread of listeria. Nat. Cell Biol. 2009, 11, 1212-1218. [CrossRef]

71. Gottschalk, M.; Xu, J.G.; Calzas, C.; Segura, M. Streptococcus suis: A new emerging or an old neglected zoonotic pathogen? Future Microbiol. 2010, 5, 371-391. [CrossRef] [PubMed]

72. Tenenbaum, T.; Papandreou, T.; Gellrich, D.; Friedrichs, U.; Seibt, A.; Adam, R.; Wewer, C.; Galla, H.J.; Schwerk, C.; Schroten, H. Polar bacterial invasion and translocation of streptococcus suis across the blood-cerebrospinal fluid barrier in vitro. Cell. Microbiol. 2009, 11, 323-336. [CrossRef] [PubMed]

73. Vanier, G.; Segura, M.; Gottschalk, M. Characterization of the invasion of porcine endothelial cells by streptococcus suis serotype 2. Can. J. Vet. Res. Rev. Can. De Rech. Vet. 2007, 71, 81-89. 
74. Benga, L.; Goethe, R.; Rohde, M.; Valentin-Weigand, P. Non-encapsulated strains reveal novel insights in invasion and survival of streptococcus suis in epithelial cells. Cell. Microbiol. 2004, 6, 867-881. [CrossRef]

75. Willenborg, J.; Fulde, M.; de Greeff, A.; Rohde, M.; Smith, H.E.; Valentin-Weigand, P.; Goethe, R. Role of glucose and ccpa in capsule expression and virulence of streptococcus suis. Microbiology 2011, 157, 1823-1833. [CrossRef]

76. Charland, N.; Nizet, V.; Rubens, C.E.; Kim, K.S.; Lacouture, S.; Gottschalk, M. Streptococcus suis serotype 2 interactions with human brain microvascular endothelial cells. Infect. Immun. 2000, 68, 637-643. [CrossRef]

77. Benga, L.; Friedl, P.; Valentin-Weigand, P. Adherence of streptococcus suis to porcine endothelial cells. J. Vet. Med. Ser. B-Infect. Dis. Vet. Public Health 2005, 52, 392-395. [CrossRef]

78. Vanier, G.; Segura, M.; Friedl, P.; Lacouture, S.; Gottschalk, M. Invasion of porcine brain microvascular endothelial cells by streptococcus suis serotype 2. Infect. Immun. 2004, 72, 1441-1449. [CrossRef]

79. Fittipaldi, N.; Segura, M.; Grenier, D.; Gottschalk, M. Virulence factors involved in the pathogenesis of the infection caused by the swine pathogen and zoonotic agent streptococcus suis. Future Microbiol. 2012, 7, 259-279. [CrossRef]

80. Sun, Y.; Li, N.; Zhang, J.; Liu, H.; Liu, J.; Xia, X.; Sun, C.; Feng, X.; Gu, J.; Du, C.; et al. Enolase of streptococcus suis serotype 2 enhances blood-brain barrier permeability by inducing il-8 release. Inflammation 2016, 39, 718-726. [CrossRef]

81. Lun, S.C.; Perez-Casal, J.; Connor, W.; Willson, P.J. Role of suilysin in pathogenesis of streptococcus suis capsular serotype 2. Microb. Pathog. 2003, 34, 27-37. [CrossRef]

82. Seitz, M.; Baums, C.G.; Neis, C.; Benga, L.; Fulde, M.; Rohde, M.; Goethe, R.; Valentin-Weigand, P. Subcytolytic effects of suilysin on interaction of streptococcus suis with epithelial cells. Vet. Microbiol. 2013, 167, 584-591. [CrossRef] [PubMed]

83. Vadeboncoeur, N.; Segura, M.; Al-Numani, D.; Vanier, G.; Gottschalk, M. Pro-inflammatory cytokine and chemokine release by human brain microvascular endothelial cells stimulated by streptococcus suis serotype 2. Fems Immunol. Med. Microbiol. 2003, 35, 49-58. [CrossRef] [PubMed]

84. Tenenbauma, T.; Matalon, D.; Adam, R.; Seibt, A.; Wewer, C.; Schwerk, C.; Galla, H.J.; Schrotena, H. Dexamethasone prevents alteration of tight junction-associated proteins and barrier function in porcine choroid plexus epithelial cells after infection with streptococcus suis in vitro. Brain Res. 2008, 1229, 1-17. [CrossRef] [PubMed]

85. Wewer, C.; Seibt, A.; Wolburg, H.; Greune, L.; Schmidt, M.A.; Berger, J.; Galla, H.J.; Quitsch, U.; Schwerk, C.; Schroten, H.; et al. Transcellular migration of neutrophil granulocytes through the blood-cerebrospinal fluid barrier after infection with streptococcus suis. J. Neuroinflammation 2011, 8, 51. [CrossRef] [PubMed]

86. Scarborough, M.; Thwaites, G.E. The diagnosis and management of acute bacterial meningitis in resource-poor settings. Lancet Neurol. 2008, 7, 637-648. [CrossRef]

87. Iovino, F.; Orihuela, C.J.; Moorlag, H.E.; Molema, G.; Bijlsma, J.J.E. Interactions between blood-borne streptococcus pneumoniae and the blood-brain barrier preceding meningitis. PLoS ONE 2013, 8, e68408. [CrossRef]

88. Van Ginkel, F.W.; McGhee, J.R.; Watt, J.M.; Campos-Torres, A.; Parish, L.A.; Briles, D.E. Pneumococcal carriage results in ganglioside-mediated olfactory tissue infection (vol 100, pg 14363, 2003). Proc. Natl. Acad. Sci. USA 2004, 101, 6834 .

89. Wartha, F.; Beiter, K.; Albiger, B.; Fernebro, J.; Zychlinsky, A.; Normark, S.; Henriques-Normark, B. Capsule and d-alanylated lipoteichoic acids protect streptococcus pneumoniae against neutrophil extracellular traps. Cell. Microbiol. 2007, 9, 1162-1171. [CrossRef]

90. Middleton, D.R.; Paschall, A.V.; Duke, J.A.; Avci, F.Y. Enzymatic hydrolysis of pneumococcal capsular polysaccharide renders the bacterium vulnerable to host defense. Infect. Immun. 2018, 86. [CrossRef]

91. Keller, L.E.; Jones, C.V.; Thornton, J.A.; Sanders, M.E.; Swiatlo, E.; Nahm, M.H.; Park, I.H.; McDaniel, L.S. Pspk of streptococcus pneumoniae increases adherence to epithelial cells and enhances nasopharyngeal colonization. Infect. Immun. 2013, 81, 173-181. [CrossRef] [PubMed]

92. Li-Korotky, H.S.; Lo, C.Y.; Banks, J.M. Interaction of pneumococcal phase variation, host and pressure/gas composition: Virulence expression of nana, hyla, pspa and cbpa in simulated otitis media. Microb. Pathog. 2010, 49, 204-210. [CrossRef] [PubMed]

93. Shainheit, M.G.; Muie, M.; Camilli, A. The core promoter of the capsule operon of streptococcus pneumoniae is necessary for colonization and invasive disease. Infect. Immun. 2014, 82, 694-705. [CrossRef] [PubMed] 
94. Iovino, F.; Molema, G.; Bijlsma, J.J.E. Platelet endothelial cell adhesion molecule-1, a putative receptor for the adhesion of streptococcus pneumoniae to the vascular endothelium of the blood-brain barrier. Infect. Immun. 2014, 82, 3555-3566. [CrossRef]

95. Uchiyama, S.; Carlin, A.F.; Khosravi, A.; Weiman, S.; Banerjee, A.; Quach, D.; Hightower, G.; Mitchell, T.J.; Doran, K.S.; Nizet, V. The surface-anchored nana protein promotes pneumococcal brain endothelial cell invasion. J. Exp. Med. 2009, 206, 1845-1852. [CrossRef] [PubMed]

96. Gratz, N.; Loh, L.N.; Mann, B.; Gao, G.; Carter, R.; Rosch, J.; Tuomanen, E.I. Pneumococcal neuraminidase activates tgf-beta signalling. Microbiology 2017, 163, 1198-1207.

97. Iovino, F.; Engelen-Lee, J.Y.; Brouwer, M.; van de Beek, D.; van der Ende, A.; Seron, M.V.; Mellroth, P.; Muschiol, S.; Bergstrand, J.; Widengren, J.; et al. Pigr and pec am-1 bind to pneumococcal adhesins rrga and pspc mediating bacterial brain invasion. J. Exp. Med. 2017, 214, 1619-1630. [CrossRef]

98. Bagnoli, F.; Moschioni, M.; Donati, C.; Dimitrovska, V.; Ferlenghi, I.; Facciotti, C.; Muzzi, A.; Giusti, F.; Emolo, C.; Sinisi, A.; et al. A second pilus type in streptococcus pneumoniae is prevalent in emerging serotypes and mediates adhesion to host cells. J. Bacteriol. 2008, 190, 5480-5492. [CrossRef]

99. Orihuela, C.J.; Mahdavi, J.; Thornton, J.; Mann, B.; Wooldridge, K.G.; Abouseada, N.; Oldfield, N.J.; Self, T.; Ala'Aldeen, D.A.; Tuomanen, E.I. Laminin receptor initiates bacterial contact with the blood brain barrier in experimental meningitis models. J. Clin. Invest. 2009, 119, 1638-1646. [CrossRef]

100. Schmidt, F.; Kakar, N.; Meyer, T.C.; Depke, M.; Masouris, I.; Burchhardt, G.; Gomez-Mejia, A.; Dhople, V.; Havarstein, L.S.; Sun, Z.; et al. In vivo proteomics identifies the competence regulon and alib oligopeptide transporter as pathogenic factors in pneumococcal meningitis. PLoS Path. 2019, 15, e1007987. [CrossRef]

101. Chen, J.Q.; Li, N.N.; Wang, B.W.; Liu, X.F.; Liu, J.L.; Chang, Q. Upregulation of cbp by ply can cause permeability of blood-brain barrier to increase meningitis. J. Biochem. Mol. Toxicol. 2019, e22333. [CrossRef] [PubMed]

102. Zysk, G.; Schneider-Wald, B.K.; Hwang, J.H.; Bejo, L.; Kim, K.S.; Mitchell, T.J.; Hakenbeck, R.; Heinz, H.P. Pneumolysin is the main inducer of cytotoxicity to brain microvascular endothelial cells caused by streptococcus pneumoniae. Infect. Immun. 2001, 69, 845-852. [CrossRef] [PubMed]

103. Mandi, L.K.; Wang, H.; Van der Hoek, M.B.; Paton, J.C.; Ogunniyi, A.D. Identification of a novel pneumococcal vaccine antigen preferentially expressed during meningitis in mice. J. Clin. Invest. 2012, 122, 2208-2220.

104. Wang, Y.; Liu, X.; Liu, Q. Nod2 expression in streptococcus pneumoniae meningitis and its influence on the blood-brain barrier. Can. J. Infect. Dis Med. Microbiol 2018, 2018. [CrossRef] [PubMed]

105. Barichello, T.; Fagundes, G.D.; Generoso, J.S.; Moreira, A.P.; Costa, C.S.; Zanatta, J.R.; Simoes, L.R.; Petronilho, F.; Dal-Pizzol, F.; Vilela, M.C.; et al. Brain-blood barrier breakdown and pro-inflammatory mediators in neonate rats submitted meningitis by streptococcus pneumoniae. Brain Res. 2012, 1471, 162-168. [CrossRef]

106. Brouwer, M.C.; Tunkel, A.R.; van de Beek, D. Epidemiology, diagnosis, and antimicrobial treatment of acute bacterial meningitis. Clin. Microbiol. Rev. 2010, 23, 467-492. [CrossRef]

107. Jones, N.; Bohnsack, J.F.; Takahashi, S.; Oliver, K.A.; Chan, M.S.; Kunst, F.; Glaser, P.; Rusniok, C.; Crook, D.W.M.; Harding, R.M.; et al. Multilocus sequence typing system for group b streptococcus. J. Clin. Microbiol. 2003, 41, 2530-2536. [CrossRef]

108. Maisey, H.C.; Doran, K.S.; Nizet, V. Recent advances in understanding the molecular basis of group $b$ streptococcus virulence. Expert Rev. Mol. Med. 2008, 10, e27. [CrossRef]

109. Nizet, V.; Kim, K.S.; Stins, M.; Jonas, M.; Chi, E.Y.; Nguyen, D.; Rubens, C.E. Invasion of brain microvascular endothelial cells by group b streptococci. Infect. Immun. 1997, 65, 5074-5081.

110. Tazi, A.; Disson, O.; Bellais, S.; Bouaboud, A.; Dmytruk, N.; Dramsi, S.; Mistou, M.Y.; Khun, H.; Mechler, C.; Tardieux, I.; et al. The surface protein hvga mediates group $\mathrm{b}$ streptococcus hypervirulence and meningeal tropism in neonates. J. Exp. Med. 2010, 207, 2313-2322. [CrossRef]

111. Lauer, P.; Rinaudo, C.D.; Soriani, M.; Margarit, I.; Maione, D.; Rosini, R.; Taddei, A.R.; Mora, M.; Rappuoli, R.; Grandi, G.; et al. Genome analysis reveals pili in group b streptococcus. Science 2005, 309, 105. [CrossRef] [PubMed]

112. Maisey, H.C.; Hensler, M.; Nizet, V.; Doran, K.S. Group b streptococcal pilus proteins contribute to adherence to and invasion of brain microvascular endothelial cells. J. Bacteriol. 2007, 189, 1464-1467. [CrossRef] [PubMed] 
113. Mu, R.; Kim, B.J.; Paco, C.; Del Rosario, Y.; Courtney, H.S.; Doran, K.S. Identification of a group b streptococcal fibronectin binding protein, sfba, that contributes to invasion of brain endothelium and development of meningitis. Infect. Immun. 2014, 82, 2276-2286. [CrossRef] [PubMed]

114. Seo, H.S.; Mu, R.; Kim, B.J.; Doran, K.S.; Sullam, P.M. Binding of glycoprotein srr1 of streptococcus agalactiae to fibrinogen promotes attachment to brain endothelium and the development of meningitis. PLoS Path. 2012, 8, e1002947. [CrossRef] [PubMed]

115. Deng, L.W.; Spencer, B.L.; Holmes, J.A.; Mu, R.; Rego, S.; Weston, T.A.; Hu, Y.; Sanches, G.F.; Yoon, S.; Park, N.; et al. The group b streptococcal surface antigen $\mathrm{i} /$ ii protein, bspc, interacts with host vimentin to promote adherence to brain endothelium and inflammation during the pathogenesis of meningitis. PLoS Path. 2019, 15, e1007848. [CrossRef]

116. Shin, S.; Maneesh, P.S.; Lee, J.S.; Romer, L.H.; Kim, K.S. Focal adhesion kinase is involved in type iii group b streptococcal invasion of human brain microvascular endothelial cells. Microb. Pathog. 2006, 41, 168-173. [CrossRef]

117. Doran, K.S.; Engelson, E.J.; Khosravi, A.; Maisey, H.C.; Fedtke, I.; Equils, O.; Michelsen, K.S.; Arditi, M.; Peschel, A.; Nizet, V. Blood-brain barrier invasion by group b streptococcus depends upon proper cell-surface anchoring of lipoteichoic acid. J. Clin. Invest. 2005, 115, 2499-2507. [CrossRef]

118. Luo, S.; Cao, Q.; Ma, K.; Wang, Z.F.; Liu, G.J.; Lu, C.P.; Liu, Y.J. Quantitative assessment of the blood-brain barrier opening caused by streptococcus agalactiae hyaluronidase in a balb/c mouse model. Sci Rep.-Uk 2017, 7, 13529. [CrossRef]

119. Kim, B.J.; McDonagh, M.A.; Deng, L.; Gastfriend, B.D.; Schubert-Unkmeir, A.; Doran, K.S.; Shusta, E.V. Streptococcus agalactiae disrupts p-glycoprotein function in brain endothelial cells. Fluids Barriers Cns 2019, 16, 1-10. [CrossRef]

120. Kim, B.J.; Hancock, B.M.; Bermudez, A.; Del Cid, N.; Reyes, E.; van Sorge, N.M.; Lauth, X.; Smurthwaite, C.A.; Hilton, B.J.; Stotland, A.; et al. Bacterial induction of snail1 contributes to blood-brain barrier disruption. J. Clin. Invest. 2015, 125, 2473-2483. [CrossRef]

121. Rose, R.; Hauser, S.; Stump-Guthier, C.; Weiss, C.; Rohde, M.; Kim, K.S.; Ishikawa, H.; Schroten, H.; Schwerk, C.; Adam, R. Virulence factor-dependent basolateral invasion of choroid plexus epithelial cells by pathogenic Escherichia coli in vitro. Fems Microbiol. Lett. 2018, 365. [CrossRef] [PubMed]

122. Kim, K.S.; Itabashi, H.; Gemski, P.; Sadoff, J.; Warren, R.L.; Cross, A.S. The k1-capsule is the critical determinant in the development of escherichia-coli meningitis in the rat. J. Clin. Invest. 1992, 90, 897-905. [CrossRef] [PubMed]

123. Cross, A.S.; Kim, K.S.; Wright, D.C.; Sadoff, J.C.; Gemski, P. Role of lipopolysaccharide and capsule in the serum resistance of bacteremic strains of escherichia-coli. J. Infect. Dis. 1986, 154, 497-503. [CrossRef] [PubMed]

124. Logue, C.M.; Doetkott, C.; Mangiamele, P.; Wannemuehler, Y.M.; Johnson, T.J.; Tivendale, K.A.; Li, G.W.; Sherwood, J.S.; Nolan, L.K. Genotypic and phenotypic traits that distinguish neonatal meningitis-associated escherichia coli from fecal e. Coli isolates of healthy human hosts. Appl. Environ. Microbiol. 2012, 78, 5824-5830. [CrossRef]

125. Teng, C.H.; Cai, M.; Shin, S.; Xie, Y.; Kim, K.J.; Khan, N.A.; Di Cello, F.; Kim, K.S. Escherichia coli k1 rs218 interacts with human brain microvascular endothelial cells via type 1 fimbria bacteria in the fimbriated state. Infect. Immun. 2005, 73, 2923-2931. [CrossRef]

126. Khan, N.A.; Shin, S.; Chung, J.W.; Kim, K.J.; Elliott, S.; Wang, Y.; Kim, K.S. Outer membrane protein a and cytotoxic necrotizing factor-1 use diverse signaling mechanisms for escherichia coli k1 invasion of human brain microvascular endothelial cells. Microb. Pathog. 2003, 35, 35-42. [CrossRef]

127. Huang, S.H.; Wan, Z.S.; Chen, Y.H.; Jong, A.Y.; Kim, K.S. Further characterization of escherichia coli brain microvascular endothelial cell invasion gene ibea by deletion, complementation, and protein expression. J. Infect. Dis. 2001, 183, 1071-1078. [CrossRef]

128. Wang, M.H.; Kim, K.S. Cytotoxic necrotizing factor 1 contributes to escherichia coli meningitis. Toxins 2013, 5, 2270-2280. [CrossRef]

129. Prasadarao, N.V. Identification of escherichia coli outer membrane protein a receptor on human brain microvascular endothelial cells. Infect. Immun. 2002, 70, 4556-4563. [CrossRef] 
130. Reddy, M.A.; Wass, C.A.; Kim, K.S.; Schlaepfer, D.D.; Prasadarao, N.V. Involvement of focal adhesion kinase in escherichia coli invasion of human brain microvascular endothelial cells. Infect. Immun. 2000, 68, 6423-6430. [CrossRef]

131. Reddy, M.A.; Prasadarao, N.V.; Wass, C.A.; Kim, K.S. Phosphatidylinositol 3-kinase activation and interaction with focal adhesion kinase in escherichia coli $\mathrm{k} 1$ invasion of human brain microvascular endothelial cells. J. Biol. Chem. 2000, 275, 36769-36774. [CrossRef] [PubMed]

132. Sukumaran, S.K.; McNamara, G.; Prasadarao, N.V. Escherichia coli k-1 interaction with human brain micro-vascular endothelial cells triggers phospholipase c-gamma1 activation downstream of phosphatidylinositol 3-kinase. J. Biol. Chem. 2003, 278, 45753-45762. [CrossRef] [PubMed]

133. Selvaraj, S.K.; Periandythevar, P.; Prasadarao, N.V. Outer membrane protein a of escherichia coli k1 selectively enhances the expression of intercellular adhesion molecule-1 in brain microvascular endothelial cells. Microb. Infect. 2007, 9, 547-557. [CrossRef] [PubMed]

134. Prasadarao, N.V.; Wass, C.A.; Stins, M.F.; Shimada, H.; Kim, K.S. Outer membrane protein a-promoted actin condensation of brain microvascular endothelial cells is required for escherichia coli invasion. Infect. Immun. 1999, 67, 5775-5783.

135. Sukumaran, S.K.; Quon, M.J.; Prasadarao, N.V. Escherichia coli k1 internalization via caveolae requires caveolin-1 and protein kinase c alpha interaction in human brain microvascular endothelial cells. J. Biol. Chem. 2002, 277, 50716-50724. [CrossRef]

136. Kim, K.J.; Elliott, S.J.; Di Cello, F.; Stins, M.F.; Kim, K.S. The k1 capsule modulates trafficking of e-coli-containing vacuoles and enhances intracellular bacterial survival in human brain microvascular endothelial cells. Cell. Microbiol. 2003, 5, 245-252. [CrossRef]

137. Yang, R.C.; Huang, F.; Fu, J.Y.; Dou, B.B.; Xu, B.J.; Miao, L.; Liu, W.T.; Yang, X.P.; Tan, C.; Chen, H.C.; et al. Differential transcription profiles of long non-coding rnas in primary human brain microvascular endothelial cells in response to meningitic escherichia coli. Sci. Rep. 2016, 6, 38903. [CrossRef]

138. Yang, R.C.; Qu, X.Y.; Xiao, S.Y.; Li, L.; Xu, B.J.; Fu, J.Y.; Lv, Y.J.; Amjad, N.; Tan, C.; Kim, K.S.; et al. Meningitic escherichia coli-induced upregulation of pdgf-b and icam-1 aggravates blood-brain barrier disruption and neuroinflammatory response. J. Neuroinflamm. 2019, 16, 101. [CrossRef]

139. Sukumaran, S.K.; Prasadarao, N.V. Escherichia coli k1 invasion increases human brain microvascular endothelial cell monolayer permeability by disassembling vascular-endothelial cadherins at tight junctions. J. Infect. Dis. 2003, 188, 1295-1309. [CrossRef]

140. Mittal, R.; Gonzalez-Gomez, I.; Goth, K.A.; Prasadarao, N.V. Inhibition of inducible nitric oxide controls pathogen load and brain damage by enhancing phagocytosis of escherichia coli k1 in neonatal meningitis. Am. J. Pathol. 2010, 176, 1292-1305. [CrossRef]

141. Shanmuganathan, M.V.; Krishnan, S.; Fu, X.W.; Prasadarao, N.V. Attenuation of biopterin synthesis prevents escherichia coli $\mathrm{k} 1$ invasion of brain endothelial cells and the development of meningitis in newborn mice. J. Infect. Dis. 2013, 207, 61-71. [CrossRef] [PubMed]

142. Liu, W.T.; Lv, Y.J.; Yang, R.C.; Fu, J.Y.; Liu, L.; Wang, H.; Cao, Q.; Tan, C.; Chen, H.C.; Wang, X.R. New insights into meningitic escherichia coli infection of brain microvascular endothelial cells from quantitative proteomics analysis. J. Neuroinflamm. 2018, 15, 291. [CrossRef] [PubMed]

143. Zhang, K.; Shi, M.J.; Niu, Z.; Chen, X.; Wei, J.Y.; Miao, Z.W.; Zhao, W.D.; Chen, Y.H. Activation of brain endothelium by escherichia coli $\mathrm{k} 1$ virulence factor cgld promotes polymorphonuclear leukocyte transendothelial migration. Med. Microbiol. Immunol. 2019, 208, 59-68. [CrossRef] [PubMed]

144. Coureuil, M.; Lecuyer, H.; Bourdoulous, S.; Nassif, X. A journey into the brain: Insight into how bacterial pathogens cross blood-brain barriers. Nat. Rev. Microbiol. 2017, 15, 149-159. [CrossRef]

145. Schneider, M.C.; Exley, R.M.; Chan, H.; Feavers, I.; Kang, Y.H.; Sim, R.B.; Tang, C.M. Functional significance of factor $\mathrm{h}$ binding to neisseria meningitidis. J. Immunol. 2006, 176, 7566-7575. [CrossRef]

146. Seib, K.L.; Scarselli, M.; Comanducci, M.; Toneatto, D.; Masignani, V. Neisseria meningitidis factor h-binding protein fhbp: A key virulence factor and vaccine antigen. Expert Rev. Vaccines 2015, 14, 841-859. [CrossRef]

147. Kim, B.J.; Shusta, E.V.; Doran, K.S. Past and current perspectives in modeling bacteria and blood brain barrier interactions. Front. Microbiol. 2019, 10, 1336. [CrossRef]

148. Stephens, D.S. Biology and pathogenesis of the evolutionarily successful, obligate human bacterium neisseria meningitidis. Vaccine 2009, 27, B71-B77. [CrossRef] 
149. Gomes, S.F.M.; Westermann, A.J.; Sauerwein, T.; Hertlein, T.; Forstner, K.U.; Ohlsen, K.; Metzger, M.; Shusta, E.V.; Kim, B.J.; Appelt-Menzel, A.; et al. Induced pluripotent stem cell-derived brain endothelial cells as a cellular model to study neisseria meningitidis infection. Front. Microbiol. 2019, 10. [CrossRef]

150. Nagele, V.; Heesemann, J.; Schielke, S.; Jimenez-Soto, L.F.; Kurzai, O.; Ackermann, N. Neisseria meningitidis adhesin nada targets beta1 integrins: Functional similarity to yersinia invasin. J. Biol. Chem. 2011, 286, 20536-20546. [CrossRef]

151. Pizza, M.; Rappuoli, R. Neisseria meningitidis: Pathogenesis and immunity. Curr. Opin. Microbiol. 2015, 23, 68-72. [CrossRef] [PubMed]

152. Unkmeir, A.; Latsch, K.; Dietrich, G.; Wintermeyer, E.; Schinke, B.; Schwender, S.; Kim, K.S.; Eigenthaler, M.; Frosch, M. Fibronectin mediates opc-dependent internalization of neisseria meningitidis in human brain microvascular endothelial cells. Mol. Microbiol. 2002, 46, 933-946. [CrossRef] [PubMed]

153. Deghmane, A.E.; Giorgini, D.; Larribe, M.; Alonso, J.M.; Taha, M.K. Down-regulation of pili and capsule of neisseria meningitidis upon contact with epithelial cells is mediated by crga regulatory protein. Mol. Microbiol. 2002, 43, 1555-1564. [CrossRef] [PubMed]

154. Berry, J.L.; Pelicic, V. Exceptionally widespread nanomachines composed of type iv pilins: The prokaryotic swiss army knives. Fems Microbiol. Rev. 2015, 39, 134-154. [CrossRef]

155. Bernard, S.C.; Simpson, N.; Join-Lambert, O.; Federici, C.; Laran-Chich, M.P.; Maissa, N.; Bouzinba-Segard, H.; Morand, P.C.; Chretien, F.; Taouji, S.; et al. Pathogenic neisseria meningitidis utilizes cd147 for vascular colonization. Nat. Med. 2014, 20, 725-731. [CrossRef]

156. Rudel, T.; Scheurerpflug, I.; Meyer, T.F. Neisseria pilc protein identified as type-4 pilus tip-located adhesin. Nature 1995, 373, 357-359. [CrossRef]

157. Nassif, X.; Beretti, J.L.; Lowy, J.; Stenberg, P.; O'Gaora, P.; Pfeifer, J.; Normark, S.; So, M. Roles of pilin and pilc in adhesion of neisseria meningitidis to human epithelial and endothelial cells. Proc. Natl. Acad. Sci. USA 1994, 91, 3769-3773. [CrossRef]

158. Morand, P.C.; Tattevin, P.; Eugene, E.; Beretti, J.L.; Nassif, X. The adhesive property of the type iv pilus-associated component pilc1 of pathogenic neisseria is supported by the conformational structure of the n-terminal part of the molecule. Mol. Microbiol. 2001, 40, 846-856. [CrossRef]

159. Virji, M. Pathogenic neisseriae: Surface modulation, pathogenesis and infection control. Nat. Rev. Microbiol. 2009, 7, 274-286. [CrossRef]

160. Carbonnelle, E.; Hill, D.J.; Morand, P.; Griffiths, N.J.; Bourdoulous, S.; Murillo, I.; Nassif, X.; Virji, M. Meningococcal interactions with the host. Vaccine 2009, 27, B78-B89. [CrossRef]

161. Virji, M.; Makepeace, K.; Ferguson, D.J.; Achtman, M.; Moxon, E.R. Meningococcal opa and opc proteins: Their role in colonization and invasion of human epithelial and endothelial cells. Mol. Microbiol. 1993, 10, 499-510. [CrossRef] [PubMed]

162. Gray-Owen, S.D. Neisserial opa proteins: Impact on colonization, dissemination and immunity. Scand. J. Infect. Dis. 2003, 35, 614-618. [CrossRef] [PubMed]

163. Sa, E.C.C.; Griffiths, N.J.; Virji, M. Neisseria meningitidis opc invasin binds to the sulphated tyrosines of activated vitronectin to attach to and invade human brain endothelial cells. PLoS Pathog 2010, 6, e1000911.

164. Simonis, A.; Hebling, S.; Gulbins, E.; Schneider-Schaulies, S.; Schubert-Unkmeir, A. Differential activation of acid sphingomyelinase and ceramide release determines invasiveness of neisseria meningitidis into brain endothelial cells. PLoS Path. 2014, 10, e1004160. [CrossRef] [PubMed]

165. Metruccio, M.M.; Pigozzi, E.; Roncarati, D.; Berlanda Scorza, F.; Norais, N.; Hill, S.A.; Scarlato, V.; Delany, I. A novel phase variation mechanism in the meningococcus driven by a ligand-responsive repressor and differential spacing of distal promoter elements. PLoS Pathog 2009, 5, e1000710. [CrossRef] [PubMed]

166. Comanducci, M.; Bambini, S.; Caugant, D.A.; Mora, M.; Brunelli, B.; Capecchi, B.; Ciucchi, L.; Rappuoli, R.; Pizza, M. Nada diversity and carriage in neisseria meningitidis. Infect. Immun. 2004, 72, 4217-4223. [CrossRef] [PubMed]

167. Capecchi, B.; Adu-Bobie, J.; Di Marcello, F.; Ciucchi, L.; Masignani, V.; Taddei, A.; Rappuoli, R.; Pizza, M.; Arico, B. Neisseria meningitidis nada is a new invasin which promotes bacterial adhesion to and penetration into human epithelial cells. Mol. Microbiol. 2005, 55, 687-698. [CrossRef]

168. Scietti, L.; Sampieri, K.; Pinzuti, I.; Bartolini, E.; Benucci, B.; Liguori, A.; Haag, A.F.; Lo Surdo, P.; Pansegrau, W.; Nardi-Dei, V.; et al. Exploring host-pathogen interactions through genome wide protein microarray analysis. Sci. Rep. 2016, 6, 27996. [CrossRef] 
169. Simonis, A.; Schubert-Unkmeir, A. Interactions of meningococcal virulence factors with endothelial cells at the human blood-cerebrospinal fluid barrier and their role in pathogenicity. Febs Lett. 2016, 590, 3854-3867. [CrossRef]

170. Lambotin, M.; Hoffmann, I.; Laran-Chich, M.P.; Nassif, X.; Couraud, P.O.; Bourdoulous, S. Invasion of endothelial cells by neisseria meningitidis requires cortactin recruitment by a phosphoinositide-3-kinase/rac1 signalling pathway triggered by the lipo-oligosaccharide. J. Cell Sci. 2005, 118, 3805-3816. [CrossRef]

171. Soyer, M.; Charles-Orszag, A.; Lagache, T.; Machata, S.; Imhaus, A.F.; Dumont, A.; Millien, C.; Olivo-Marin, J.C.; Dumenil, G. Early sequence of events triggered by the interaction of neisseria meningitidis with endothelial cells. Cell. Microbiol. 2014, 16, 878-895. [CrossRef] [PubMed]

172. Takahashi, H.; Watanabe, H.; Kim, K.S.; Yokoyama, S.; Yanagisawa, T. The meningococcal cysteine transport system plays a crucial role in neisseria meningitidis survival in human brain microvascular endothelial cells. Mbio 2018, 9. [CrossRef] [PubMed]

173. Slanina, H.; Hebling, S.; Hauck, C.R.; Schubert-Unkmeir, A. Cell invasion by neisseria meningitidis requires a functional interplay between the focal adhesion kinase, src and cortactin. PLoS ONE 2012, 7, e39613. [CrossRef] [PubMed]

174. Schubert-Unkmeir, A.; Sokolova, O.; Panzner, U.; Eigenthaler, M.; Frosch, M. Gene expression pattern in human brain endothelial cells in response to neisseria meningitidis. Infect. Immun. 2007, 75, 899-914. [CrossRef] [PubMed]

175. Sa, E.C.C.; Griffiths, N.J.; Murillo, I.; Virji, M. Neisseria meningitidis opc invasin binds to the cytoskeletal protein alpha-actinin. Cell. Microbiol. 2009, 11, 389-405. [CrossRef]

176. Coureuil, M.; Lecuyer, H.; Scott, M.G.H.; Boularan, C.; Enslen, H.; Soyer, M.; Mikaty, G.; Bourdoulous, S.; Nassif, X.; Marullo, S. Meningococcus hijacks a beta 2-adrenoceptor/beta-arrestin pathway to cross brain microvasculature endothelium. Cell 2010, 143, 1149-1160. [CrossRef]

177. Schubert-Unkmeir, A.; Konrad, C.; Slanina, H.; Czapek, F.; Hebling, S.; Frosch, M. Neisseria meningitidis induces brain microvascular endothelial cell detachment from the matrix and cleavage of occludin: A role for mmp-8. PLoS Path. 2010, 6, e1000874. [CrossRef]

178. Coureuil, M.; Mikaty, G.; Miller, F.; Lecuyer, H.; Bernard, C.; Bourdoulous, S.; Dumenil, G.; Mege, R.M.; Weksler, B.B.; Romero, I.A.; et al. Meningococcal type iv pili recruit the polarity complex to cross the brain endothelium. Science 2009, 325, 83-87. [CrossRef]

179. Waage, A.; Brandtzaeg, P.; Halstensen, A.; Kierulf, P.; Espevik, T. The complex pattern of cytokines in serum from patients with meningococcal septic shock-association between interleukin-6, interleukin-1, and fatal outcome. J. Exp. Med. 1989, 169, 333-338. [CrossRef]

180. Sokolova, O.; Heppel, N.; Jagerhuber, R.; Kim, K.S.; Frosch, M.; Eigenthaler, M.; Schubert-Unkmeir, A. Interaction of neisseria meningitidis with human brain microvascular endothelial cells: Role of map- and tyrosine kinases in invasion and inflammatory cytokine release. Cell. Microbiol. 2004, 6, 1153-1166. [CrossRef]

181. Watt, J.P.; Wolfson, L.J.; O’Brien, K.L.; Henkle, E.; Deloria-Knoll, M.; McCall, N.; Lee, E.; Levine, O.S.; Hajjeh, R.; Mulholland, K.; et al. Burden of disease caused by haemophilus influenzae type b in children younger than 5 years: Global estimates. Lancet 2009, 374, 903-911. [CrossRef]

182. Zarei, A.E.; Almehdar, H.A.; Redwan, E.M. Hib vaccines: Past, present, and future perspectives. J. Immunol. Res. 2016. [CrossRef] [PubMed]

183. Bakaletz, L.O.; Novotny, L.A. Nontypeable haemophilus influenzae (nthi). Trends Microbiol. 2018, 26, 727-728. [CrossRef] [PubMed]

184. Doran, K.S.; Banerjee, A.; Disson, O.; Lecuit, M. Concepts and mechanisms: Crossing host barriers. Cold Spring Harb. Perspect. Med. 2013, 3, a010090. [CrossRef]

185. Van Ham, S.M.; van Alphen, L.; Mooi, F.R.; van Putten, J.P. Phase variation of h. Influenzae fimbriae: Transcriptional control of two divergent genes through a variable combined promoter region. Cell 1993, 73, 1187-1196. [CrossRef]

186. Cundell, D.R.; Gerard, N.P.; Gerard, C.; Idanpaan-Heikkila, I.; Tuomanen, E.I. Streptococcus pneumoniae anchor to activated human cells by the receptor for platelet-activating factor. Nature 1995, 377, 435-438. [CrossRef]

187. Swords, W.E.; Ketterer, M.R.; Shao, J.; Campbell, C.A.; Weiser, J.N.; Apicella, M.A. Binding of the non-typeable haemophilus influenzae lipooligosaccharide to the paf receptor initiates host cell signalling. Cell. Microbiol. 2001, 3, 525-536. [CrossRef] 
188. Radin, J.N.; Orihuela, C.J.; Murti, G.; Guglielmo, C.; Murray, P.J.; Tuomanen, E.I. Beta-arrestin 1 participates in platelet-activating factor receptor-mediated endocytosis of streptococcus pneumoniae. Infect. Immun. 2005, 73, 7827-7835. [CrossRef]

189. Caporarello, N.; Olivieri, M.; Cristaldi, M.; Scalia, M.; Toscano, M.A.; Genovese, C.; Addamo, A.; Salmeri, M.; Lupo, G.; Anfuso, C.D. Blood-brain barrier in a haemophilus influenzae type a in vitro infection: Role of adenosine receptors a(2a) and a(2b). Mol. Neurobiol. 2018, 55, 5321-5336. [CrossRef]

190. Wispelwey, B.; Lesse, A.J.; Hansen, E.J.; Scheld, W.M. Haemophilus influenzae lipopolysaccharide-induced blood brain barrier permeability during experimental meningitis in the rat. J. Clin. Invest. 1988, 82, 1339-1346. [CrossRef]

191. Wispelwey, B.; Hansen, E.J.; Scheld, W.M. Haemophilus influenzae outer membrane vesicle-induced blood-brain barrier permeability during experimental meningitis. Infect. Immun. 1989, 57, 2559-2562. [PubMed]

192. Parisi, D.N.; Martinez, L.R. Intracellular haemophilus influenzae invades the brain: Is zyxin a critical blood brain barrier component regulated by tnf-alpha? Virulence 2014, 5, 645-647. [CrossRef] [PubMed]

193. Kostyanev, T.S.; Sechanova, L.P. Virulence factors and mechanisms of antibiotic resistance of haemophilus influenzae. Folia Med. 2012, 54, 19-23. [CrossRef]

194. Yau, B.; Hunt, N.H.; Mitchell, A.J.; Too, L.K. Bloodbrain barrier pathology and cns outcomes in streptococcus pneumoniae meningitis. Int. J. Mol. Sci. 2018, 19, 3555. [CrossRef] [PubMed]

195. Ferrieri, P.; Burke, B.; Nelson, J. Production of bacteremia and meningitis in infant rats with group-b streptococcal serotypes. Infect. Immun. 1980, 27, 1023-1032.

196. Nassif, X.; Bourdoulous, S.; Eugene, E.; Couraud, P.O. How do extracellular pathogens cross the blood-brain barrier? Trends Microbiol. 2002, 10. [CrossRef]

(C) 2019 by the authors. Licensee MDPI, Basel, Switzerland. This article is an open access article distributed under the terms and conditions of the Creative Commons Attribution (CC BY) license (http://creativecommons.org/licenses/by/4.0/). 